\title{
Studies of technogenic soils in Poland: past, present, and future perspectives
}

\author{
Łukasz Uzarowicz ${ }^{1 *}$, Przemysław Charzyński², Andrzej Greinert ${ }^{3}$, Piotr Hulisz ${ }^{2}$, Cezary Kabała ${ }^{4}$, \\ Grzegorz Kusza ${ }^{5}$, Wojciech Kwasowski ${ }^{1}$, Artur Pędziwiatr ${ }^{1}$ \\ ${ }^{1}$ Warsaw University of Life Sciences - SGGW, Institute of Agriculture, Department of Soil Science, Nowoursynowska Str. 159, building no. 37, \\ 02-776 Warszawa, Poland, ORCID iD: https://orcid.org/0000-0003-1448-2445 (W. Kwasowski), https://orcid.org/0000-0002-6253-4302 (A. Pędziwiatr) \\ ${ }^{2}$ Nicolaus Copernicus University in Toruń, Faculty of Earth Sciences and Spatial Management, Department of Soil Science and Landscape \\ Management, Lwowska St. 1, 87-100, Toruń, Poland, ORCID iD: https://orcid.org/0000-0003-1467-9870 (P. Charzyński) https://orcid.org/0000-0003- \\ 3494-9997 (P. Hulisz) \\ ${ }^{3}$ University of Zielona Gora, Institute of Environmental Engineering, Department of Geoengineering and Reclamation, Prof. Z. Szafrana Str. 15 , \\ 65-516 Zielona Góra, Poland; ORCID iD: https://orcid.org/0000-0002-1194-2082 \\ ${ }^{4}$ Wrocław University of Environmental and Life Sciences, Institute of Soil Science and Environmental Protection, Grunwaldzka Str. 53 , \\ 50-375 Wrocław, Poland; ORCID ID: https://orcid.org/0000-0001-9796-3716 (C. Kabała) \\ ${ }^{5}$ University of Opole, Department of Land Protection, Oleska Str. 22, 45-052 Opole, Poland, ORCID iD: https://orcid.org/0000-0003-4329-8700 \\ (G. Kusza) \\ * dr hab. Ł. Uzarowicz, lukasz_uzarowicz@sggw.edu.pl, ORCID iD: https://orcid.org/0000-0002-7982-404X
}

Received: 07.10 .2020

Accepted: 11.12.2020

Associated editor: Ł. Mendyk

\section{Keywords}

Technosols

Urban soils

Mine soils

SUITMA

\begin{abstract}
For a long time, the soils covering areas strongly transformed by human were ignored in scientific discourse. Also, practice did not care much about these soils because of their unproductivity. Only the large post-mining areas reclaimed and transformed into a forest or agricultural land were more interesting both for science and practice. In the case of post-mining areas the term "soilless land" was used for a long time, especially in relation to areas which were not reclaimed. In this paper, the past studies (until the end of $20^{\text {th }}$ century) of technogenic soils in Poland were described. Technogenic soils of urban and industrial areas appeared in scientific considerations in Poland in the second half of the $20^{\text {th }}$ century. In those times, soil properties on disposal sites were mainly investigated as a basic information for further design of technical and biological reclamation on disposal sites. Two Polish scientists should be emphasised as the world pioneers in concepts and studies of technogenic soils: (1) Michał Strzemski, who proposed a classification scheme for soils in urban and industrial areas, as well as listed the tasks for future studies of these soils, and (2) Tadeusz Skawina, who focused on the dynamic and directions of the soil-forming processes on the mine spoils in the context of their reclamation. Moreover, studies of technogenic soils in the last two decades were also shown in the paper. From the beginning of the $21^{\text {st }}$ century the scientific research gained momentum. Nowadays, Polish researchers have great achievements in studying technogenic soils, including investigation of their properties, genesis, evolution, classification, biological features etc. Furthermore, we drew some outlines for future studies of Technosols.
\end{abstract}

\section{Introduction}

Technogenic soils, i.e. soils created or significantly transformed by humans in the industrial and urbanised areas, are recently among the most intensively studied soil groups (Kabała et al., 2020). The studies have been carried out in many countries, after both scientists and politician have considered that majority of human population already lives in the areas, where such soil predominate. Poland has experienced tremendous industrial growth and urbanisation after the second world war, which also, unfortunately, had an extensive negative impact on the soil cover, regarding both its naturalness and quality (Bielska et al., 2015). It is clear since a long time, that the sites, including their soils, degraded by mining, industry, waste storage, transportation etc. may create a risk for human health and for the other organisms, thus require special attention, monitoring and reclamation (Sutkowska and Teper, 2015; Karczewska and Kabała, 2017; Warchulski et al., 2019; Józefowska et al., 2020).

The aim of the present paper is to show the achievements and contribution of Polish research to knowledge about the soils of urban, industrial, traffic, mining and military areas (SUITMA), regarding their properties, concept of their genesis 
and development. Most of these soils fulfil in majority the criteria for technogenic soils in a sense of Polish Soil Classification (Kabała et al., 2019) and many fulfil criteria for Technosols, as defined by WRB classification (IUSS Working Group WRB, 2015). Historical studies (till the end of $20^{\text {th }}$ century) are presented, as well as the main contemporary (last 20 years) study directions are described. Moreover, general future perspectives for Technosol studies are outlined.

\section{History of studies of technogenic soils in Poland}

Research involving the human-affected soils in Poland has its long history, as it started in mid-1950s. It has to be emphasised that the terms "technogenic soils" and "Technosols" were not used in that times. More frequently used terms were for example "mine/urban soils" or "soils of mine/urban areas". Studies of technogenic soils from the very beginning acted multidirectional. In addition to analysing of soil properties, some effort was focused on the spatial diversity, classification and cartography, possibilities of urban land use and reclamation and remediation. Experts in soil science and reclamation of degraded sites dealt with these topics in parallel.

\subsection{Soils in urban areas}

The first elements of urban soil description appeared in the 1950s. In that time, a new field of science - urban physiography - was developed and the necessity of detailed urban environment description, including soils, was noted (Dziewoński, 1955). In a request, Strzemski (1955) proposed an original concept of soil classification in urban areas, based on his extensive observations rather than detailed studies. Strzemski (1955) highlighted the necessity of pedological investigations and indicated a number of detailed tasks for future urban soil studies, that covered:

1) the initial phases of the soil-forming process from the natural and artificial materials,

2) biological activation of soils by bacterial inoculation,

3) activation of ,artificial” soil formation of sandy/skeletal soils by adding the natural clay minerals (bentonites),

4) the use the synthetic substances to accelerate the structure formation in urban soils,

5) the weathering processes on slag and mine heaps,

6) fertilization and chemical transformation of soils in urban and mining areas,

7) physical and water properties of various kinds of excavated materials as possible soil substrates,

8) agrotechnical methods for soils devastated or transformed by man,

9) phyto-melioration of soils developed from anthropogenic substrates.

Strzemski's (1955) concepts were completely new and not immediately found a positive response, in particular in case of urban soils.

Detailed studies of urban soils in Poland have commenced since early 1970s. They were mainly focused on chemical properties of soils of urban green areas, especially the roadside greenery, in Warsaw (Dobrzański et al., 1971; Czarnowska, 1975, 1978; Czerwiński, 1978) and Wrocław (Roszyk and Roszykowa, 1975). The studies concerned in particular the soil salinization (due to the use of salts for de-icing of roads and pavements) and contamination with trace elements, in particular with lead. Some research was conducted also in the big urban parks, like Łazienkowski Park (Dobrzański et al., 1975a, 1975b) and Saski Park in Warsaw (Dobrzański et al., 1977). Based on these studies, a new extensive proposal of urban soil classification was derived (Konecka-Betley et al., 1984).

Parallel to pedologists, studies on anthropogenic materials in urbanised areas were carried out by researchers from other disciplines, e.g. civil engineering. Racinowski (1976) divided the dumped soils into construction embankments and uncontrolled embankments. The first ones resulted from controlled activity, i.e. planned construction of earthworks and soil strengthening. A term 'uncontrolled embankments' described various types of landfills.

The investigations during next two decades have focused mainly on soil contamination, including the content of trace elements in plants and animals. The studies, carried out in various green areas of Warsaw, showed that human activity has destroyed the natural arrangement of soil profiles, which is evidenced by: (a) the change of morphology of soil profiles, (b) the emergence of calcium carbonates (e.g. from cement), (c) change of soil reaction from acidic to alkaline, (d) accumulation of organic substance in the upper layers of anthropogenic soils, and (e) accumulation of trace elements; the latter two phenomena - mostly in the topsoil layers (Czarnowska and Konecka-Betley, 1977; Czarnowska, 1980; Czarnowska et al., 1983, 1995, 1996, 1999). The highest accumulation was reported for $\mathrm{Cd}, \mathrm{Zn}, \mathrm{Pb}$ and $\mathrm{Cu}$, while much lower for $\mathrm{Mo}, \mathrm{Fe}, \mathrm{Ni}$ and $\mathrm{Cr}$. The highest concentration of metals in the soils, plants and animals was detected in the surroundings of the streets and industrial plants. Czarnowska (1980) claimed that the accumulation of trace elements in the soils, mosses, tree leaves, grasses and animal tissues can be a measurable indicator of the antropization of urban soils and, in a broader sense, the antropization of the urban environment. Studies on chemical transformation of urban soils, including transformation of soil reaction, salinity and contamination with trace elements were carried out also in other Polish cities, including Łódź (Czarnowska and Walczak, 1988), Lublin (Filipek and Badora, 1992; Kukier 1985, 1991), Kraków (Komornicki, 1986), Bydgoszcz (Malczyk et al., 1996), Szczecin (Wojcieszczuk, 1981, 1982; Wybieralski and Maciejewska, 1999), and numerous small towns, including Oława (Roszyk and Strojek, 1983) and Tomaszów Mazowiecki (Kabała, 1995).

The research on the spatial variability of urban soils in Warsaw, continued by Czerwiński and Pracz (1990a, 1990b), has emphasised the great role of construction and demolition waste (CDW) in the further soil formation. The authors distinguished a number of soil types and subtypes, such as mechanically transformed soils (with mixed horizons, truncated topsoil, etc.), dumped soils (further divided according to the type of artefacts) and chemically transformed soils (saline soils, soils contaminated with heavy metals). 
Extensive research on urban soils was initiated in Zielona Góra in 1990s (Greinert, 1998a, 1998b, 1998c, 1999a, 1999b, 2000a, 2000b, 2000c, 2000d, 2003), concerning the morphological transformation of soil profiles, changes of soil physical and physico-chemical properties, as well as soil pollution and respective remediation techniques. The latter aspects are particularly important during the dynamic grow of the cities or remodelling of their internal structure. During that process, many former industrial sites change their functions that requires a recognition of the risks, commonly related to soil contamination (Greinert, 2000b).

\subsection{Soils in industrial and mining areas}

The studies of technogenic soils in industrial and mining areas in Poland date back to 1950s. Skawina (1958a, 1958b) started his field research and experiments aiming in biological improvement of industrial waste lands (brownfields) in 1955. Skawina has illustrated the initial stages of soil formation on the waste heaps in the Upper Silesia region, where bituminous coal has been mined since centuries back. Various forms of soil deterioration resulting from atmospheric pollution (dust and smoke) and mining activity (Skawina, 1958a), as well as the succession of natural vegetation and the changes in physical properties and chemical composition of the parent rock in various phases of soil development (Skawina, 1958b) were discussed. The author noticed that soils on the dumps from coal mining are still on the initial developmental stage, even in case of the oldest dumps, covered with tree stands or used as agricultural lands. He found that the intensity of parent material transformation is the highest in the first stage of soil formation, then it becomes slower and less evident. Also, Skawina (1958b) paid attention to the strong spatial heterogeneity of soils on mine dumps. He noticed that differences in the direction and advancement of the soil-forming processes are mainly determined by the following factors: (1) type of material and age of the dump, (2) height, shape and severity of erosion, (3) weathering of rocks, (4) thermal activity of coal dumps due to burning of coal remains dispersed inside the dump, (5) microclimate, (6) water properties, (7) chemical properties, and (8) type of vegetation in adjacent areas. Skawina (1958b) stated that bringing surface layers of mine wastes to chemical equilibrium is the most important aim of the biological reclamation of dumps. This allows to skip over several dozen years of the natural soil development under the slow plant succession and, consequently, allows to reclaim the dumps within much shorter time of the years instead of decades. Skawina and his co-workers are pioneers of land reclamation in Poland, who gave the basis for preparation of plans/projects of restoration of areas destroyed by industrial and mining activity (e.g. Skawina, 1969; Skawina and Trafas, 1971; Bolewski and Skawina, 1972; Skawina et al., 1974; Eckes et al., 1986).

Strzyszcz (1978) conducted lysimetric (column) experiments, which imitated a natural weathering of wastes on the coal mining dumps and gave an insight into possible directions of weathering processes in young technogenic soils. He found that (1) the wastes from bituminous coal mines are very diverse in terms of their physical and chemical properties as well as mineral composition; (2) properties of soils on surfaces of dumps are controlled by the rate of weathering of soil substrate; (3) the salinity of substrate changes as the weathering proceeds; (4) $\mathrm{pH}$ changes very dynamically in the weathered wastes; (5) mineral fertilization (mainly with nitrogen) is necessary in the first years of reclamation to improve the plant growth and to allow plants to survive seasonal droughts and near-ground frosts; (6) phosphorus fertilization should be done three and four years after plant introduction. One of the most important issue which should be recognized before plant introduction is a susceptibility of mine spoils to acidification due to sulphide weathering (Strzyszcz, 1978); therefore, he developed a rapid laboratory method based on the oxidation of wastes by hydrogen peroxide (Strzyszcz, 1988).

The studies of soils on dumps of open-pit lignite mines and their reclamation were initiated by Skawina (1963) and then continued by other researchers (e.g. Bender, 1980, 1983; Gołębiowska and Bender, 1983; Gilewska, 1991; Bender and Gilewska, 2004; Bender, 1995; Krzaklewski and Mikłaszewski, 1996; Szafrański and Stachowski, 1997). One of the most important achievements gained in the "Konin" lignite mine (central Poland) was relatively rapid transformation of the dumped wastes into fertile agricultural soils. It must be, however, stated that the wastes from the open-pit lignite mining noticeably differed from the wastes of bituminous coal mining, as the former mainly consisted of the Pleistocene materials, like glacial till and glacio-fluvial sands (Znamirowska-Karaś, 2001).

The remediation methods developed in the Konin region, known as "reclamation model of the Polish Academy of Sciences”, although successfully applied in Konin, could not be universally applied due to high diversity of materials deposited on mine dumps. An adaptation of reclamation methods for phytotoxic acidic spoils from lignite open-pit mine was conducted by the group of Greinert (1988). The concept presumed strong stimulation of primary soil forming processes by agricultural engineering and high doses of NPK fertilization. The main problem to solve was an extremely low $\mathrm{pH}$ (about 3) caused by pyrite and marcasite weathering, which eliminated introduced plants and facilitated erosion on the uncovered slops. The use of multistage soil reclamation with the target afforestation with Scots pine effectively hampered the erosion (Greinert, 1995, 1996, 1997). The research showed that the elements of reclamation which are crucial to reach their expected effectiveness are as follows: (1) homogenization of soil properties by deep mechanical cultivation, (2) neutralization of soil acidity, (3) fertilization with large NPK doses (unusual for ordinary forest cultivation), 4) preventing the suppression of pine growth by herbaceous vegetation, especially grasses.

Numerous studies have been carried out on the disposal sites of thermal power station ash (fly ash and bottom ash). Majority of the works focused on the methods of their reclamation and the influence of the reclamation on properties of developing technogenic soils (Maciak, 1978; Maciak et al., 1974, 1976a, 1976b, 1976c, 1979; Wysocki, 1988; Gilewska, 2004, 2006). Pioneer research concerning the weathering and soil-forming processes in soils formed from ash was conducted in the 1970s by Maciak and his co-workers (Maciak et al., 1976c). They have shown that 
reclamation and long-term cultivation of grasses and legumes caused the following changes in the properties of the ash substrate: (1) change in the colour from light to dark grey, (2) accumulation of pedogenic soil organic matter in the topsoil layer, (3) increase in the rate of cellulose decomposition indicating an increasing microbiological activity, (4) decrease in alkalinity, and (5) increase in carbonate content. That study was one of the first attempts in the world to discuss the pedogenic aspects of ash transformation into a soil. In 1980s, the works aiming to determine the chemical composition and the content of selected radionuclides in soils and plants cultivated on a bituminous coal dump were conducted by Rosik-Dulewska and Dulewski (1988).

Strzyszcz (1980) performed a thorough analysis of initial technogenic soils developed on the tailings from $\mathrm{Zn}$ and $\mathrm{Pb}$ ore mining and processing in the Upper Silesia. Physical and chemical properties, salinity, contents of trace elements $(\mathrm{Zn}, \mathrm{Pb}, \mathrm{Cd}$, $\mathrm{Mn}, \mathrm{Cu}$ ), and microbiological properties of soils were studied. The properties of technogenic soils on the disposal sites near $\mathrm{Zn}$ and $\mathrm{Pb}$ mines in Trzebinia (south Poland) were then examined by Trafas $(1988,1996)$. Similar studies, conducted on the tailing ponds receiving the fine-textured wastes from $\mathrm{Cu}$ ore processing in Legnica region (Bogda and Chodak, 1995) have confirmed, that the technogenic soils developing from the tailings have unfavourable physical properties, are highly saline, alkaline and are contaminated with trace metals, that all together hampers the plant succession and soil development. Kabata-Pendias (1977) reported similar conclusions based on a pot experiments using the tailings from $\mathrm{Cu}$ ore processing.

Adamczyk (1965) and Swałdek (1983) studied the soils developed on old dumps of the abandoned iron ore mines in north-western region of the Holy Cross Mts., south-central Poland. Properties of these technogenic soils were compared with natural soils occurring in the surrounding of mine dumps. The natural soils were sandy and strongly acidic as they were developed from carbonate-free sandy parent materials, while the anthropogenic soils were mesotrophic and eutrophic, because the mine wastes were rich in carbonates and clay. The emergence of technogenic parent materials led to the formation of mesophilous beech and fir forests while the natural soils surrounding dumps were covered with various acidophilus communities.

Historical metal ore mining was widespread in the Sudeten Mountains, south-western Poland, marked with numerous waste dumps, either intentionally reclaimed or left for natural succession. Pedological studies in the Złoty Stok, initiated in 1990s (Szerszeń et al., 1994) have shown locally extreme soil contamination with arsenic and other metals, connected with widespread presence of the mining and smelting wastes in soils and on the soil surface. Arsenic and other trace elements were also found at high concentrations in the soils on the dumps in the Kaczawskie Mountains, where they often influence the plant and ground-water quality (Karczewska, 1999).

The pedological studies were conducted in 1980s and 1990s in sites of the former sand/gravel exploitation located along the Bóbr river, western Poland. Soils in these sites are featured by strong compaction, especially in the subsoil horizons, very low air capacity, acidic reaction, low content of organic matter and nutrients, as well as low soil enzymatic activity (Drab, 1988).
Reclamation of these soils was carried out with initial mechanical soil preparation (deep ploughing) and mineral fertilization with high NPK doses (Drab, 1998). Although a noticeable soil fertility improvement was observed, some physical soil properties remained defective, as evidenced by excessive soil compaction and imbalanced soil air-water relations (Greinert and Drab, 2000). The horizon with gleyic properties was noted at the depth of 40-60 cm below the surface (Drab, 2002, 2004).

In the 1980s, the first Polish researches on the enrichment of soils in industrial areas with ferromagnetic iron as an indicator of the deposition of industrial pollutants was conducted (Strzyszcz et al., 1988). The studies concerned the analysis of the ferromagnetic properties of technogenic and urban soils located in Upper Silesia (Strzyszcz, 1989a; Strzyszcz, 1989b; Strzyszcz et al., 1994).

\section{Present studies of technogenic soils in Poland}

The $21^{\text {st }}$ century brought a dynamic increase in the research on technogenic soils in Poland. These soils have become the subject of interest of most Polish research groups dealing with soils science. Further development of knowledge about land reclamation, properties of different technogenic soils, as well as other soils degraded by human activity was expressed by numerous books or university script publications. In connection with the $7^{\text {th }}$ SUITMA conference held in 2013 in Toruń, north Poland, a few books were published (Charzyński et al., 2013a, 2013b) which gathered together chapters presenting studies on soils in urban, industrial, traffic, mining and military areas.

\subsection{Technogenic soils in urban areas}

In addition to numerous new investigations focusing on detailed aspects, some attempts have been made to derive more generalized conclusions. As an effect, the papers comparing soil characteristics in selected cities have appeared (Greinert, 2002; Hulisz et al., 2018a). Soil research has significantly extended using modern analytical methods. This gave the opportunity to recognize the processes occurring in SUITMAs, and to improve their classification.

The main lines of research concerning soils in urban areas (including Technosols) can be described as follows:

- Soil chemistry, especially contamination with heavy metals and rare earths elements, their spatial distribution, solubility and mobility (Kozanecka et al., 2000; Pasieczna, 2003; Kabała and Wilk, 2004; Kwasowski and Markiewicz, 2007; Kabala et al., 2009, 2011; Kostecki et al., 2015; Kwasowski et al., 2016; Gąsiorek et al., 2017; Plak, 2018; Różański et al., 2018; Lewińska et al., 2019);

- Impact of salt use for road de-icing on the salinization of urban soil and conditions for plants (Brogowski et al., 2000; Czerniawska-Kusza et al., 2004; Kochanowska and Kusza, 2010; Łuczak et al., 2020);

- Impact of soil sealing on soil properties (Charzyński et al., 2011a, 2011c, 2017b, 2018b; Piotrowska-Długosz and Charzyński, 2015; Mendyk and Charzyński, 2016); 
- Soil development on buildings and other constructions, including military fortifications (Charzyński et al., 2011b; Charzyński and Hulisz, 2013; Charzyński et al., 2015a; Markiewicz et al., 2018; Pardela et al., 2020);

- Soils of urban areas - urban agriculture, allotment gardens, parks and other green areas (Oleszczuk and Baran, 2005; Charzyński et al. 2018a; Beroigui et al., 2020);

- Importance of artefacts for soil properties and their further potential development, with particular emphasis on the construction and demolition wastes (Greinert, 2003; Greinert et al., 2013a; Greinert and Kostecki, 2019);

- Scale of anthropogenic soil transformation in the urban green areas (Licznar and Licznar, 2005; Licznar et al., 2007; Kabała et al., 2010; Dradrach and Bogacz, 2013; Musielok et al., 2018);

- Pedodiversity analysis in the urban, industrial and traffic areas; its contribution to urban soil mapping (Kabała and Chodak, 2002; Skiba et al., 2013; Greinert, 2015; Hulisz et al., 2018a; Pindral et al., 2020);

- Classification of anthropogenic soils (Polish Soil Classification, 2011, 2019; Charzyński et al., 2013c, 2017a; Kabała et al., 2018, 2019);

- Urban and industrial areas history as a factor of soil development (Greinert, 2003; Chudecka, 2009; Mazurek et al., 2016; Charzyński and Hulisz, 2017; Hulisz et al., 2018a, 2018b);

- Functions of soils in the urban environment (Greinert, 2017);

- Characterization of soil properties and geochemistry in the military areas (Jankowski and Sewerniak, 2013; Jankowski et al., 2013; Lewińska et al., 2017);

- Identification of urban soil contamination using magnetometric methods (Magiera and Strzyszcz, 2000; Wawer et al., 2015b, 2017; Łukasik et al., 2015; Łuczak and Kusza, 2019).

Polish researchers made a great contribution to recognise properties and functioning of Ekranic Technosols, i.e. the soils covered with impermeable and nearly-impermeable layers (pavement, asphalt, concrete, etc.) (Charzyński et al., 2011a, 2011c, 2017b, 2018b; Kostecki et al., 2020). The impact of the soil sealing on microbiological and physicochemical properties of Ekranic Technosols was investigated in Toruń (Piotrowska-Długosz and Charzyński, 2015). Moreover, soil sealing degree as a factor influencing urban soil contamination with polycyclic aromatic hydrocarbons (PAHs) was studied (Mendyk and Charzyński, 2016). It was found that totally sealed soils are better preserved from atmospheric pollutants, including PAHs. Charzyński et al. (2017b) used indicators, such as geoaccumulation index (Igeo), enrichment factor (EF) and pollution load index (PLI), to quantitatively determine the impact of soil sealing on the content of elements ( $\mathrm{Cd}, \mathrm{Cr}, \mathrm{Cu}, \mathrm{Hg}, \mathrm{Fe}, \mathrm{Ni}, \mathrm{Pb}, \mathrm{Zn}$ ). It was found that the sealing has influenced the soil properties and Ekranic Technosols are less exposed to the accumulation of pollutants. Very important issue in the context of soil sealing are the water problems commonly noted in the cities (Kostecki et al., 2020).

A few soil studies were also made to examine morphological and chemical properties of soils located within cemeteries and mass murder camps (Charzyński et al. 2011c, 2015b; Majgier and Rahmonov, 2012; Majgier et al., 2014).
Along with the dynamic development of cities, the share of the traffic areas (roads, railways, airports) significantly increases. These specific areas, both in terms of construction and exploitation, have long aroused the interest of soil scientists. Currently, research is conducted on the composition and chemistry of soils in roadside areas (Kostecki et al., 2015). It was demonstrated that the road modernisation is typically connected with replacement of soil material, thus those soils are relatively young and not polluted (Kostecki et al., 2015). Pesticide residues in soils along railways were studied by Winiarek and Kruk (2017). The properties of soils in a Toruń airfield were investigated by Charzyński et al. (2013d).

The urban soils tend to be highly heterogeneous in terms of their properties and spatial distribution (Greinert, 2015). Therefore the spatial analysis of impact of the urban sprawl and other dynamic processes on soil resources in cities seems to be one of the most significant current line of research (Hulisz et al., 2018a). Maps of soil diversity can be valuable tools in a supporting the urban spatial planning (Kabała and Chodak, 2002; Skiba et al., 2013). Pindral et al. (2020) proposed the original method based on landscape metrics and GIS for measuring pedodiversity index (PI) which enables to identify the areas of the most strongly human-transformed soils and soil losses. Research is currently ongoing on field validation of this method and its application in spatial-temporal analysis of the soil cover. Another studies (Gąsiorek et al., 2017; Kowalska et al., 2016; Krupski et al., 2017) showed that urban soils can be an archive of urban area development and activities of citizens in the past. Kabala et al. (2018) have suggested unification of variable tests for phosphorus determination in anthropogenic soils and argued for Mehlich-3 procedure as the most universal for a wide selection of soils.

An important element of discussion on technogenic soils is quantity and quality of artefacts in these soils. Urban soils are largely enriched in construction and demolition wastes (CDW), rubbish, slag, ash, translocated rock fragments, sludge, and household wastes (Greinert, 2003; Greinert et al., 2013a; Hulisz et al., 2018a). It causes changes in the soil composition, its sorption capacity and water retention, and thus affects the circulation of water and elements in soil. CDW as a mixture of different materials often contains lime and other compounds that are chemically highly reactive; whereas, other CDW compounds, like construction sands and gravels, are considered chemically inert.

The effect of urbanization on soil properties and soil organic carbon accumulation in topsoil was examined (Oktaba et al., 2014, 2018). The contents of polycyclic aromatic hydrocarbons (PAHs) were determined in the humus horizons of soils of park gardens situated in city centres (Kraków, Lublin, Miasteczko Śląskie, Szczecin, Zabrze, and Zamość) and in their outskirts (Bielińska et al., 2011). It was found that, the PAH content was much higher in soils of parks situated in the city centres than in soils of parks situated in the outskirts.

The pollution sources and distribution of $\mathrm{Pb}, \mathrm{Cd}$, and $\mathrm{Hg}$ in Urbic Technosols in Wrocław were investigated by Gmochowska et al. (2019). The studies showed that $\mathrm{Pb}$ and $\mathrm{Cd}$ concentrations in technogenic soils were higher than in the non-technogenic 
soils. Furthermore, distribution of metallic elements in Urbic Technosols was more erratic relative to the more predictable one in not contaminated soils due to many sources of pollution. Other studies in Wrocław (Hołtra and Zamorska-Wojdyła, 2018) showed that soils are contaminated mostly by $\mathrm{Zn}, \mathrm{Cu}$, and $\mathrm{Ni}$. These studies did not demonstrate any correlation between metal concentrations in soils and the distance from the city centre, but confirmed the importance of local pollution sources (Kabala et al., 2009). Similar findings were reported by Dradrach and Bogacz (2013).

Magnetometric studies have been used to identify pollutants in urban soils caused both by emissions from municipal sources (low emission, traffic pollution, etc.) and as a result of the negative impact of industrial plants (Strzyszcz and Rachwał, 2010; Szuszkiewicz et al., 2018). Research on the impact of traffic pollution on the quality of roadside soils was conducted in several cities in Europe and Asia (Wawer et al., 2015a; 2015b; Łuczak and Kusza, 2019). A significant increase in the amount of pollutants deposited as a result of emissions, including $\mathrm{Cd}, \mathrm{Ni}$, and Pt, was indicated. Research conducted in the area of the Upper Silesian agglomeration revealed a significant relationship between the magnitude of magnetic susceptibility and the degree of transformation of soils, including technogenic and urban soils (Strzyszcz et al. 1994; Łukasik et al., 2015; Magiera et al., 2016a, 2016b).

Magnetic susceptibility measurements were also used to identify technogenic horizons in soil profiles. Identification of technogenic layers using magnetometric methods allows for a precise indication of the transformed site in the soil profile. Such studies were carried out, for example, along the Vistula Cross-Cut, which indicated the presence of technogenic soils created during its construction (Hulisz et al., 2015; Kusza et al., 2018). Identification of technogenic layers using magnetometric methods allows for precise detection of the antropogenic horizons in the soil profile (Magiera et al., 2006).

\subsection{Technogenic soils on buildings}

The first modern studies of the soils formed on buildings were conducted in Torun by Charzyński et al. (2011b), Charzyński and Hulisz (2013), and Charzyński et al. (2015a). Authors proposed a new name to classify these soils, i.e. edifisols (Latin aedificium = building). Edifisols are common component of urban landscapes, being a result of initial, relatively natural pedogenetic processes taking place on different constructed structures such as building's roofs, walls or gutters, bridges. They include both allochthonous material transported from the surrounding areas (e.g. dust, plants litter) and autochthonous organic material associated mainly with fresh litter from overgrowing plants. Input and accumulation of soil organic matter are very important for the formation of edifisols. Markiewicz et al. (2018) argued for the distinguishing of a new type of humus - the techno humus system - characterized by relatively low degree of humification and predominance of humic acids in the composition of humus. Edifisols were introduced as a subtype of technogenic soils in Polish Soil Classification (2019), the first national system recognizing such soils.
The other kind of soils on buildings are Technosols prepared by a human by deposition of thick layer of soil material on/over constructions made by man, such as underground garages, tunnels, as well as the above-ground bridges ("ecological passages" for animals), "green roofs”, etc. Such soils, called Konstruktosols, have been introduced to the Polish Soil Classification (2019) as a subtype of technogenic soils. Studies on these soils are still in an initial phase, and only the soils developed on the military constructions (fortifications) have been documented more extensively, e.g. in Toruń and Wrocław. Typically, these soils have a coarse texture (sandy texture class), guarantying better drainage of the concrete construction, but unfavourable for vegetation due to insufficient water retention (Jankowski et al., 2013; Pardela et al., 2020).

\subsection{Technogenic soils in industrial and mining areas}

Technogenic soils in industrial and mining areas have been intensively investigated in Poland in recent years. As long as the past studies were focused mainly on the properties of the mining wastes in terms of their reclamation in the disposal site, at present the studies are focused on the natural functioning of the soils on dumps with emphasis on the transformations of technogenic substrate into a soil, influence of plant cover (introduced by human or from spontaneous succession) on soil properties, initiation of soil-forming and biological processes, etc. (Znamirowska-Karaś, 2002). The relatively new and rapidly growing topic are ecotoxical studies focused on soils in the contaminated industrial sites, carried out to support their remediation strategy (Karczewska and Kabała, 2017).

Previous studies related to reclamation of bituminous coal mine dumps were continued (Strzyszcz and Harabin, 2004). Moreover, studies aiming in characterization of Technosols developed on mine dumps of abandoned bituminous coal mines were also carried out by other authors, including previously omitted sites as in the Wałbrzych mining region, south-western Poland (e.g. Maciejewska and Bogda, 2003; Gwiżdż and Kabała, 2011; Gwiżdż et al., 2011; Szopka et al., 2011). At the same time, a thorough investigation of technogenic soil materials have been carried out on the burning coal mining dumps in areas of historical bituminous coal exploitation (Kruszewski, 2013; Fabiańska et al., 2016). The studies permitted, for example, for identification of unusual mineralogy of these materials, as well as the composition of organic compounds occurring on the burning dumps.

Technosols developed on the overburden heaps of open-pit lignite mines in Poland were studied in order to determine their properties, assess the advances of soil-forming processes in these soils (e.g. Znamirowska-Karaś, 2001; Wójcik, 2003; Pająk and Krzaklewski, 2006; Wójcik and Krzaklewski, 2007, 2019; Spychalski et al., 2016), and to determine the soil organic carbon stocks in soils after reclamation (Świtoniak et al., 2011; Pietrzykowski and Daniels, 2014). Numerous authors (Krzaklewski and Wójcik, 2008; Gilewska and Otremba, 2007, 2013; Pietrzykowski, 2014; Pietrzykowski and Krzaklewski, 2007; Greinert et al., 2015) noted that land reclamation of post-industrial areas have accelerated soil development. 
The long-term effects of the forest reclamation of post-mining areas on the strongly acidic sands in Łęknica have been constantly under investigation. A systematic formation of pine forests has been noticed on the areas subjected to reclamation 30 years ago (Greinert et al., 2009; Greinert et al., 2013b). Along with this process, significant carbon accumulation in soils has been noted both in the litter layer and in the mineral horizon beneath (Greinert et al., 2018). The most important changes have been observed in $\mathrm{O}$ and $\mathrm{A}$ horizons due to biological activity. Authors noted that the soil forming process has still been at a very early initial stage (Greinert et al., 2013b).

Very intense studies of technogenic soils from industrial wastes produced by $\mathrm{Zn}$ and $\mathrm{Pb}$ mines were conducted in recent years, including soils on the old calamine dumps and contemporary tailing ponds (e.g. Krzaklewski and Pietrzykowski, 2002; Trafas and Eckes, 2007; Pietrzykowski et al., 2011). The research confirmed high contamination of these soils with trace elements, such as $\mathrm{Zn}, \mathrm{Pb}, \mathrm{Cd}$, As and $\mathrm{Tl}$ (Cabała and Teper, 2007; Cabała et al., 2008; Jerzykowska et al., 2014). Changes of properties during the pedogenesis of Spolic Technosols driven by natural restoration of disposal sites receiving wastes from $\mathrm{Zn}$ and $\mathrm{Pb}$ ore mines in south Poland were studied by Ciarkowska et al. (2016). It was found that the contents of soil organic carbon and total nitrogen, available potassium and phosphorus including dehydrogenase activity increased with age of soils. Pedogenesis resulted also in the improvement of soil structure by the development of fine aggregates, which created porosity able to store water. Relationship between vegetation and soil properties on a dump of a historical Zn-Pb mine in Tarnowskie Góry was investigated (Pająk et al., 2018). Moreover, contamination of soils in the vicinity of the tailings ponds receiving wastes from zinc and lead mining and processing, as well as its impact on microbial functional diversity and enzyme activity in forest soils near olkusz were studied e.g. by Krzaklewski et al. (2004), Chodak et al. (2013) and Pająk et al. (2016).

The copper ore mining and processing, beneficial for the economy of south-western Poland, also created one of the largest environmental issues for the region, related to the emissions from $\mathrm{Cu}$ smelters and various negative impacts of the tailing impoundments on soil environment (Karczewska et al., 2017; Kabala et al., 2020). The tailings stored in several impoundments, due to their low water capacity, low fertility, high alkalinity and high concentration of residual trace metals, are extremely unfavourable for living organisms (Chodak et al., 2005; Gawron et al., 2007; Krawczyńska et al., 2015; Kasowska et al., 2018). Thus, several attempts were undertaken to improve the tailings physical and chemical properties, aimed to accelerate their biological reclamation, using various kinds of organic substrates, including sewage sludge and geocomposites (Karczewska and Milko, 2010; Karczewska et al., 2011, 2013; Gersztyn and Karczewska, 2012; Kordas and Tasz, 2012; Spiak et al., 2012; Gersztyn et al., 2013; Marczyk et al., 2013; Kuc et al., 2019).

The studies on technogenic and contaminated soils in the areas of historical metal ore mining in the Sudeten Mountains, south-western Poland, have been continued by Karczewska and co-workers. The investigations were concentrated in the Kaczawskie Mountains (around the Żeleźniak Hill) and the Złote
Mountains (Złoty Stok area), where enormous concentrations of arsenic and heavy metals are present in soils bearing the mining and smelting wastes (Karczewska et al., 2001, 2007; Karczewska, 2014). The studies focused on the solubility of arsenic and metals and the threats for human health from arsenic release to ground and surface waters and its uptake by consumable plants (Karczewska et al., 2005; Karczewska and Bogda, 2006; Krysiak and Karczewska, 2007). Moreover, solubility and toxicity of metals in the soils on mining and smelting heaps and in their surrounding was tested under artificially modified conditions, to support the selection of the most reliable and safe remediation technology (Karczewska et al., 2013; 2018; Dradrach et al., 2019, 2020a, $2020 b, 2020 \mathrm{c}$ ). The changes of selected properties of the initial soils developed on the afforested dump of copper ore mining wastes were also studied by Wójcik and Kowalik (2006). Apart from the above-mentioned studies, also concentrations of lanthanides in soils of historical mining sites in Poland were studied (Karczewska et al., 2019).

Another group of soils intensively studied in last years were the Spolic Technosols developed on mine dumps containing iron sulphides located near the abandoned Fe sulphide mines and coal mines. The studies (Uzarowicz et al., 2008; Uzarowicz, 2011; Uzarowicz and Skiba, 2011; Uzarowicz et al., 2011, 2012; Uzarowicz and Maciejewska, 2012; Uzarowicz, 2013; Uzarowicz and Skiba, 2013) allowed to determine the properties and geochemistry of these soils, and also enabled the recognition of the most important mineral transformation tracks (in particular Fe sulphide and clay minerals alterations). The research allowed to improve the definitions of the thionic horizon and sulphuric material in relation to Technosols (Uzarowicz and Skiba, 2011) in the $3^{\text {rd }}$ edition of the World Reference Base for Soil Resources (IUSS Working Group WRB, 2015). Furthermore, on the basis of the results (Uzarowicz, 2011), supported by Charzyński et al. (2013c), the new qualifier Radiotoxic was added to the WRB classification (IUSS Working Group WRB, 2015). Fungal abundance and diversity (Stępniewska et al., 2020) and microbiological soil activity (Uzarowicz et al., 2020; Wolińska et al., 2020) as the indicators of soil development following the reclamation of the former Fe sulphide and uranium mining area in Rudki was investigated.

Also, the studies of technogenic soils developed from ash, common waste from thermal power stations, were continued in Poland in the last two decades. The effects of reclamation of a lignite combustion waste disposal site with different tree species based on field experiments were investigated (Strączyńska et al., 2004; Strączyńska and Strączyński, 2007, 2008; Krzaklewski et al., 2012; Pietrzykowski et al., 2010a, 2010b, 2013, 2018a, 2018b; Weber et al., 2015; Żołnierz et al., 2016; Gilewska et al., 2020). Organic matter properties in the topsoil layer of technogenic soils developed from ash were determined by Strączyńska et al. (2009). Carbon and macronutrient budgets under alder plantation grown on a reclaimed ash landfill were examined by Woś et al. (2020) and mercury concentration in the ash soils and in tissue of alder used to reclaim the combustion waste disposal site was determined by Woś et al. (2019). Uzarowicz and Zagórski (2015), and Uzarowicz et al. (2017, 2018a, 2018b) recognized physical and chemical properties of 
the Spolic Technosols developed from ash from coal and lignite combustion as the basis for soil classification. They determined morphological, physico-chemical and mineralogical indicators of Technosols transformation, as well as developed a concept of evolution of the Technosols developed from ash under existing environmental conditions.

The physical, physico-chemical and water properties, as well as ion leachability from the topsoil layer of the Spolic Technosols developed from soda industry wastes in Krakow were studied by Wójcik and Zawadzki (2011) and Boroń et al. (2016). Sutkowska and Teper (2015) and Sutkowska et al. (2015) studied Technosols developed on the old heap of wastes from soda ash industry in Jaworzno and Podzols in the surroundings of the heap. It was concluded that despite enrichment of the topsoil horizon on the top of the heap with trace elements ( $\mathrm{Cd}, \mathrm{Cr}, \mathrm{Ni}, \mathrm{Pb}$ and $\mathrm{Zn}$ ), the current contamination of the local soils is insignificant.

Some studies were focused on technogenic soils affected by salinization and sodification in the industrial area of the Inowrocław city (Hulisz et al., 2018b). There are waste ponds where solid and semi-liquid industrial wastes produced during the manufacturing of the soda ash by the Solvay method were stored. The research revealed that eolian supply of mineral material from the soda waste ponds and locally its transport by surface water runoff can favour very high accumulation of carbonates of technogenic origin in the topsoil (over $40 \% \mathrm{CaCO}_{3}$ by weight). It has been also shown that despite the small acreage, these soils can be of great importance in the functioning of local habitats and ecosystems. Chemical degradation of soils has contributed, paradoxically, to the increase in biodiversity through the succession of unique and legally protected salt-tolerance plants such as Salicornia europaea, Aster tripolium, Triglochin maritima, Spergularia salina, etc. (e.g. Piernik et al., 2015).

The first symptoms of soil-forming processes and the transformation of technogenic soil properties during the natural succession and reclamation in an opencast sand quarries in southern Poland were investigated by Kowalik and Wójcik (2005), Pietrzykowski and Krzaklewski (2007), and Pietrzykowski et al. (2017). Similar studies were also conducted in northern Poland (Orzechowski et al., 2008; Smólczyński and Orzechowski 2010; Smólczyński et al., 2020). The studies showed that during technical reclamation, humus horizon was restored, as well as soil properties and soil production potential became similar to soil properties prior to exploitation.

The large attention was paid to the properties of Technosols in the sulphur mining sites (including the soils highly contaminated with sulphur) and to the assessment of the results of their reclamation (Gołda, 2003; Kowalik, 2004; Gołda et al., 2005; Woś et al., 2014; Likus-Cieślik and Pietrzykowski, 2017; Likus-Cieślik et al., 2017, 2018, 2019; Pietrzykowski and Likus-Cieślik, 2018).

Analyses of biological and ecological properties of soils in reclaimed areas were studied in recent years. Biological parameters of the soils in a former sulphur mine were investigated by Siwik-Ziomek et al. (2018) and Lemanowicz et al. (2020). The influence of tree species and faunal bioturbation on the carbon sequestration, chemical and microbial properties of the soil at three post-mining sites (Piaseczno - abandoned sulphur mine, Szczakowa - opencast sand quarry, and Bełchatów - open-pit lignite mine) afforested with pine, birch, oak, and alder were carried out by Józefowska et al. (2016, 2017, 2019), Świątek et al. (2019) and Woś et al. (2018). Moreover, Józefowska et al. (2020) investigated activity of enchytraeids as an indicator of biological reclamation of post-mining soils.

Unique chemical composition (unbalanced concentration of $\mathrm{Mg}$ and other nutrients, high content of $\mathrm{Ni}$ and $\mathrm{Cr}$ ) and unfavourable physical properties were reported for soils developing on the dumps associated with serpentinite mining and crushing near Nasławice and Szklary, Lower Silesia, south-western Poland (Kabała and Szlachta, 2000; Karczewska et al., 2001). Kierczak et al. (2008) compared mobility of metallic elements in Technosol derived from slag after Ni-ore processing with naturally Ni-enriched peridotite-derived Cambisol in the Szklary Massif (Lower Silesia). The studies showed that mobility of metallic elements with lithogenic origin is relatively lower compared to elements with anthropogenic origin except for $\mathrm{Ni}$ which was more mobile in peridotite-derived Cambisol. In the other studies, it was demonstrated that the soils developed in the disposal site of slag from historical $\mathrm{Cu}$ metallurgy in Miedzianka (Lower Silesia) were strongly contaminated with $\mathrm{Cu}, \mathrm{Zn}, \mathrm{As}$, and $\mathrm{Pb}$ (Kierczak et al., 2013). The most important factors that control pedogenesis in Cu-slag deposition site in Miedzianka and mobility of metallic elements were: (a) porosity of slag, (b) phase composition of slag that depends i.e. on the cooling rate, and (c) soil properties ( $\mathrm{pH}$, organic matter content).

The effect of soil organic acids on metallic elements mobilization from slag, being the parent material for technogenic soils in Miedzianka, were studied by Potysz et al. (2017, 2018). Authors demonstrated that: (a) the root exudates (i.e., citric acid, alanine, serine, glutamic acid, etc.) contribute to the mobilization of $\mathrm{Cu}, \mathrm{Zn}$, and $\mathrm{Pb}$ from slag to larger extent compared to fulvic and humic acids, regardless of the initial $\mathrm{pH}$ of the solution; (b) root exudates enhance the glass dissolution in slag compared to demineralized water, regardless of the initial pH; (c) dissolution of sulphides and fayalite is controlled by $\mathrm{pH}$. It was found that the litter-derived solutions (from Picea abies and $\mathrm{Fa}$ gus sylvatica) enhance the glass dissolution in a slag (Potysz et al., 2019). Furthermore, interactions of slags with Acidithiobacillus thiooxidans which mimic extremely acidic conditions on slag dump revealed relatively high metallic elements mobilization in slags (up to $92 \%$ of $\mathrm{Zn}$ ).

Important aspect influencing pedogenesis of technogenic soils developed from industrial wastes is the mineral transformation during waste weathering. Bril et al. (2008) identified secondary minerals (i.e. gypsum, jarosite, anglesite) in the heap of slag from Zn-ore processing (Świętochłowice, Upper Silesia). Pietranik et al. (2018) applied an Automated SEM-EDS to extend the recognition of mineral phases during the slag weathering. Warchulski et al. (2019) applied a combination of methods (SEMEDS, XRD, EM) to track the migration paths of metallic elements in slag heap in Ruda Śląska-Wirek (Upper Silesia). The study evidenced the slag weathering by the identification of secondary phases and an enrichment of effluents in metallic elements.

Other studies of Spolic Technosols in Poland in recent years included studies of geochemistry and mineralogy of technogenic soils developed on old mine heaps of abandoned iron ore mines 
(Swęd and Niedzielski, 2018), as well as determination of geochemical background in soils in the vicinity of abandoned pyrite-uranium, copper, and zinc-lead mines (Gałuszka et al., 2015, 2016, 2018; Migaszewski et al., 2015).

Research in the field of environmental magnetometry, conducted in recent years in industrial areas in Poland, mainly focused on the influence of various industries on soil properties and the level of pollution in these areas. A measurable impact on degradation and formation of technogenic soils was found as a result of the emission of pollutants from the coke industry (Rachwał et al., 2015), cement industry (Gołuchowska and Wróbel, 2018), and metallurgy (Rachwał et al., 2017).

\section{Future perspectives}

Technogenic soils are nowadays among the most intensively studied soils. It is expected that in the nearest future the intensity of investigations will further increase. Despite a vast knowledge about Technosols, there are still many topics to develop and scientific problems to address. It seems that future studies of technogenic soils should be more interdisciplinary, complex, and should focus on functioning of these soils in the environment/landscape. Moreover, the classification of these soils should be continuously developed basing on the new knowledge which will be gained in the future.

According to the authors, the following issues should be developed in the nearest future in terms of examination of technogenic soils, not only in Poland, but also in other countries:

1) Advanced research on construction and demolition wastes and communal wastes as a parent material for technogenic soils - chemical reactivity of a different wastes, the course and the rate of weathering, taking into account various forms of deposition (admixtures, monolayers, deposits of high thickness);

2) Influence of soil property changes on the evolution of soils in industrial or mining areas;

3) Methods and techniques for improving the urban soils (especially Technosols) towards their higher water retention;

4) Methods and techniques of the protection of reclaimed soils against erosion;

5) Behaviour of plastics in soils environment, in particular in urban soils;

6) Soil mapping and spatial analysis using advanced GIS and statistical methods;

7) Genesis, directions of pedogenic processes and evolution of Spolic Technosols developed from diverse mining and industrial wastes, which should be investigated using a wide range of methods, including pedological, mineralogical, micromorphological and submicromorphological ones;

8) Genesis and evolution of Technosols in different climatic and environmental conditions;

9) Determination of indicators for quality assessment of Spolic Technosols developed from diverse mining and industrial wastes to support the remediation paths and methods, as well as to approximate their future impact on the environment and humans;
10) Health risk assessment of various types of technogenic soils;

11) Composition and transformations of soil organic matter in Technosols, also in terms of soils organic carbon sequestration in these soils;

12) Biology, microbiology, and ecology of technogenic soils, as well as interactions between anthropogenic soils substrate and biota;

13) Ecosystem services provided by technogenic soils.

\section{Concluding remarks}

The examination of technogenic soils, i.e. human-constructed or human-transformed soils, have a long tradition in Poland, initiated as early as in 1950s. Unfortunately, the reports of Polish researchers were in majority published in Polish, which limited spreading the remarks, ideas and solutions to the other countries. Two Polish scientists should be emphasised as the world pioneers in concepts and studies of technogenic soils: (1) Michał Strzemski, who in 1950s proposed a classification scheme for soils in urban and industrial areas, as well as listed the tasks for future studies of these soils, and (2) Tadeusz Skawina, who since 1950s successfully focused on the dynamic and directions of the soilforming processes on the mine spoils in the context of their reclamation. Moreover, Polish researchers had great achievements in such scientific areas like (1) toxic element contamination of soils and plants in urban and industrial areas, (2) soil-forming processes in soils developed from ash and slag, (3) reclamation of mine and industrial waste disposal sites and studies of Technosols developed in such sites. Currently, the most important scientific areas, where Polish researchers have significant achievements are (4) origin, properties, functions and spatial diversity of soils in urbanized areas, (5) transformation of soils developed from different anthropogenic substrates, including reclaimed soils, (6) contamination of soils in urban and industrial areas, with emphasis on the risk assessment for humans, and (7) concepts, naming and classification of technogenic soils. Undoubtedly, the future studies will provide the knowledge necessary for reliable management of technogenic soils, considered the most common soils of the urbanized ecosystems inhabited by man.

\section{References}

Adamczyk, B., 1965. Secondary transformations of the soil and plant cover in the northwestern region of the Świętokrzyskie Mts. formerly under mining exploitation. Roczniki Gleboznawcze - Soil Science Annual 15 (supl.), 437-442. (in Polish with English abstract)

Bender, J., 1980. Biological reclamation of the post-mining dumps. International Agricultural Jornal of CMEA (Council for Mutual Economic Assistance) 3, 50-55.

Bender, J., 1983. Theoretical base of technogenous landscape recultivation. Recultivation of technogenous areas. Matraalja Coal Mining Co., Gyongyos, 113-118.

Bender, J., 1995. Rekultywacja terenów pogórniczych w Polsce. Zeszyty Problemowe Postępów Nauk Rolniczych 418, 75-86.

Bender, J., Gilewska, M., 2004. Reclamation in the light of investigations and implementation. Roczniki Gleboznawcze - Soil Science Annual 55(2), 29-46. (in Polish with English abstract) 
Beroigui, M., Naylo, A., Walczak, M., Hafidi, M., Charzyński, P., Świtoniak, M., Różański, S., Boularbah, A., 2020. Physicochemical and microbial properties of urban park soils of the cities of Marrakech, Morocco and Torun, Poland: Human health risk assessment of fecal coliforms and trace elements, Catena 194, 104673. https://doi.org/10.1016/ j.catena.2020.104673

Bielińska, E.J., Kawecka-Radomska, M., Kłos, A., 2011. Impact of urban factors on the content of polycyclic aromatic hydrocarbons in soils of park gardens. Roczniki Gleboznawcze - Soil Science Annual 62(2), 16-22. (in Polish with English abstract)

Bielska, A., Turek, A., Maciejewska, A., Bożym, K., 2015. The issue of agricultural land protection in the process of suburbanization. Infrastructure and Ecology of Rural Areas, IV, 1, 1035-1045. (in Polish with English abstract)

Bogda, A., Chodak, T., 1995. Niektóre właściwości fizyczne i skład mineralogiczny osadów poflotacyjnych ze zbiornika „Gilow”. Zeszyty Problemowe Postępów Nauk Rolniczych 418, 415-420.

Bolewski, A., Skawina, T., 1972. Experimental application of montmorillonite clays for recultivation of sands. Prace Mineralogiczne 30. PAN, Oddział w Krakowie. Wydawnictwa Geologiczne, Warszawa.

Boron, K., Klatka, S., Ryczek, M., Liszka, P., 2016. The formation of the physical, physico-chemical and water properties reclaimed and not reclaimed sediment reservoir of the former Cracow soda plant „Solvay”. Acta Scientiarum Polonorum, Formatio Circumiectus 15(3), 35-43. (in Polish with English abstract)

Bril, H., Zainoun, K., Puziewicz, J., Courtin-Nomade, A., Vanaecker, M., Bollinger, J.C., 2008. Secondary phases from the alteration of a pile of zinc-smelting slag as indicators of environmental conditions: An example from Świętochłowice, Upper Silesia, Poland. Canadian Mineralogist 46, 1235-1248. https://doi.org/10.3749/canmin.46.5.1235

Brogowski, Z., Czarnowska, K., Chojnicki, J., Pracz, J., Zagórski, Z., 2000. Influence of salt stress on chemical composition of trees leafs from Łodź city area. Roczniki Gleboznawcze - Soil Science Annual 51(1/2), 17-28. (in Polish with English abstract)

Cabała, J., Teper, L., 2007. Metalliferous constituents of rhizosphere soils contaminated by $\mathrm{Zn}-\mathrm{Pb}$ mining in Southern Poland. Water Air and Soil Pollution 178, 351-362. https://doi.org/10.1007/s11270-006-9203-1

Cabała, J., Zogala, B., Dubiel, R., 2008. Geochemical and geophysical study of historical $\mathrm{Zn}-\mathrm{Pb}$ ore processing waste dump areas (Southern Poland). Polish Journal of Environmental Studies 17(5), 693-700.

Charzyński, P., Hulisz, P., 2013. Soils forming on buildings in Toruń. [In:] Charzyński, P., Hulisz, P., Bednarek, R. (Eds.), Technogenic Soils of Poland. Polish Society of Soil Science, Torun, pp. 81-93.

Charzyński, P., Hulisz, P., 2017. The case of Toruń, Poland. [In:] Maxine, J.L., Kye-Hoon, J.K., Morel, J.-L., Burghardt, W., Charzyński, P, Shaw, R.K., (Eds.), Soils within cities. Global approaches to their sustainable management - composition, properties, and functions of soils of the urban environment. Schweizerbart Science Publisher, pp. 123-128.

Charzyński, P., Bednarek, R., Błaszkiewicz, J., 2011a. Morphology and properties of Ekranic Technosols in Torun and Cluj-Napoca. Roczniki Gleboznawcze - Soil Science Annual 62(2), 48-53. (in Polish with English abstract)

Charzyński, P., Bednarek, R., Chmurzyński, M., 2011b. Properties of soils forming on the buildings in Torun city. [In:] Jankowski, M. (Ed.), Selected Problems of Genesis, Systematics, Management and Soil Protection in Region of Kuyavia and Pomerania. PTSH, PTG, Torun, pp. 11-28. (in Polish)

Charzyński, P., Bednarek, R., Świtoniak, M., Żołnowska, B., 2011c. Ekranic Technosols and Urbic Technosols of Toruń Necropolis. Geologia 53(4), 179-185. https://doi.org/10.6001/geologija.v53i4.1905

Charzyński, P., Hulisz, P., Bednarek, R., (eds.), 2013a. Technogenic Soils of Poland. Polish Society of Soil Science, Torun.

Charzyński, P., Markiewicz, M., Świtoniak, M., (eds.), 2013b. Technogenic Soils Atlas. Polish Society of Soil Science, Torun.
Charzyński, P., Bednarek, R., Greinert, A., Hulisz, P., Uzarowicz, Ł., 2013c. Classification of technogenic soils according to WRB system in the light of Polish experiences. Soil Science Annual 64(4), 145-150. https://doi.org/10.2478/ssa-2013-0023

Charzyński, P., Bednarek, R., Mendyk, Ł., Świtoniak, M., Pokojska-Burdziej, A., Nowak, A., 2013d. Ekranosols of Toruń airfield, [In:] Charzyński, P., Hulisz, P., Bednarek, R. (Eds.), Technogenic Soils of Poland. Polish Society of Soil Science, Toruń, pp. 173-190.

Charzyński, P., Hulisz, P., Bednarek, R., Piernik, A., Winkler, A., Chmurzyński, M., 2015a. Edifisols - a new soil unit of technogenic soils. Journal of Soils and Sediments 15(8), 1675-1686. https://doi. org/10.1007/s11368-014-0983-4

Charzyński, P., Markiewicz, M., Majorek, M., Bednarek, R., 2015b. Geochemical assessment of soils in the German Nazi concentration camp in Stutthof (Northern Poland). Soil Science and Plant Nutrition 61, sup1, 47-54, https://doi.org/10.1080/00380768.2014.1000232

Charzyński, P., Galbraith, J.M., Kabała, C., Kühn, D., Prokofeva, T.V., Vasenev, V.I., 2017a. Classification of urban soils. [In:] Maxine, J.L., KyeHoon, J.K., Morel, J.-L., Burghardt, W., Charzyński, P, Shaw, R.K., (Eds.), Soils within cities. Global approaches to their sustainable management - composition, properties, and functions of soils of the urban environment. Schweizerbart Science Publisher, 93-106.

Charzyński, P., Plak, A., Hanaka, A., 2017b. Influence of the soil sealing on the geoaccumulation index of heavy metals and various pollution factors. Environmental Science and Pollution Research 24(5), 48014811. https://doi.org/10.1007/s11356-016-8209-5

Charzyński, P., Bednarek, R., Hudańska, P., Świtoniak, M., 2018a. Issues related to classification of garden soils from the urban area of Torun, Poland. Soil Science and Plant Nutrition 64:2, 132-137. https://doi. org/10.1080/00380768.2018.1429833

Charzyński, P., Hulisz, P., Piotrowska-Długosz, A., Kamiński, D., Plak, A., 2018b. Sealing Effects on Properties of Urban Soils. [In:] Rattan, L., Stewart, B.A., (Eds.), Urban Soils. CRC Press, Boca Raton - London - New York, 155-174. https://doi.org/10.1201/9781315154251

Chodak, M., Gołębiewski, M., Morawska-Płoskonka, J., Kuduk, K., Niklińska, M., 2013. Diversity of microorganisms from forest soils differently polluted with heavy metals. Applied Soil Ecology 64, 7-14. https://doi.org/10.1016/j.apsoil.2012.11.004

Chodak, T., Kaszubkiewicz, J., Mizera, A., 2005. Researches of soil-forming value of flotation tailings and waste rock disposal site K-I in the Iwiny region in the aspect of their susceptibility to reclamation works. $\mathrm{Cu}-$ prum 1,57-95.

Chudecka, J., 2009. Charakterystyka substratu glebowego w warstwie antropogenicznej najstarszej części Szczecina. Wyd. Uczelniane ZUT w Szczecinie, $110 \mathrm{pp}$.

Ciarkowska, K., Gargiulo, L., Mele, G., 2016. Natural restoration of soils on mine heaps with similar technogenic parent material: A case study of long-term soil evolution in Silesian-Krakow Upland Poland. Geoderma 261, 141-150. https://doi.org/10.1016/j.geoderma.2015.07.018

Czarnowska, K., 1975. Występowanie metali ciężkich w glebach zieleńców warszawskich. Roczniki Nauk Rolniczych, Ser. A, 101, 159-167.

Czarnowska, K., 1999. Heavy metals in lawn soils of Warsaw. Roczniki Gleboznawcze - Soil Science Annual 50(1/2), 31-40. (in Polish with English abstract)

Czarnowska, K., 1978. Zmiany zawartości metali ciężkich w glebach i roślinach z terenu Warszawy jako wskaźnik antropogenizacji środowiska. Zeszyty Naukowe SGGW-AR, 106, 71.

Czarnowska, K., 1980. Heavy metals accumulation in soils, plants and some animals from Warsaw area. Roczniki Gleboznawcze - Soil Science Annual 31(1), 77-115. (in Polish with English abstract)

Czarnowska, K., 1995. Soils and plants in urban environment. Zeszyty Problemowe Postępów Nauk Rolniczych PAN 418, I, 111-115. (in Polish)

Czarnowska, K., 1996. Total content of heavy metals in parent rocks as reference background levels of soils. Roczniki Gleboznawcze 
- Soil Science Annual 47 (suppl.), 43-50. (in Polish with English summary)

Czarnowska, K., Gworek, B., Kozanecka, T., Latuszek, B., Szafrański, E., 1983. Heavy metals content in soils as indicator of urbanization. Polish Ecological Studies 9(1-2), 63-79.

Czarnowska, K., Konecka-Betley, K., 1977. Wpływ zanieczyszczeń atmosfery na właściwości gleb i akumulację metali ciężkich w glebach i roślinach na terenie Warszawy. Człowiek i Środowisko 1(4), 73-90. (in Polish)

Czarnowska, K., Walczak, J., 1988. Distribution of zinc, lead and manganese in soils of Łódź city. Roczniki Gleboznawcze - Soil Science Annual 39(1), 19-27.

Czerniawska-Kusza, I., Kusza, G., Dużyński, M., 2004. Effect of deicing salts on urban soils and health status of roadside trees in the Opole region. Environmental Toxicology 19, 296-301.

Czerwiński, Z., 1978. Wpływ chemicznej technologii odśnieżania ulic na gleby i roślinność drzewiastą aglomeracji miejskich. Zeszyty Naukowe SGGW-AR, 104.

Czerwiński, Z., Pracz, J., 1990a. Soils [In:] Environment of Warsaw. Varsaviana Publ., 197-212. (in Polish)

Czerwiński, Z., Pracz, J., 1990b. Gleby i kierunki ich transformacji w warunkach presji urbanistycznej. Centralny Program Badań Podstawowych "Funkcjonowanie układów ekologicznych w warunkach zurbanizowanych”. Systematyka i cechy gleb miejskich. Wyd. SGGW, 58, 41-57.

Dobrzański, B., Borek, S., Czarnowska, K., Czerwiński, Z., Czępińska-Kamińska, D., Kępka, M., Konecka-Betley, K., Kusińska, A., Mazurek, A., Pracz, J., 1975a. Badania gleboznawcze Parku Łazienkowskiego w Warszawie w nawiązaniu do ochrony środowiska. Cz. 1. Charakterystyka gleb. Roczniki Nauk Rolniczych, Ser. A, 101(1), 101-140.

Dobrzański, B., Czarnowska, K., Czerwiński, Z., Konecka-Betley, K., Pracz, J., 1975b. Badania gleboznawcze Parku Łazienkowskiego w Warszawie w nawiązaniu do ochrony środowiska. Cz. 2. Wpływ aglomeracji miejskiej na gleby i rośliny. Roczniki Nauk Rolniczych, Ser. A, 101(1), 141-158.

Dobrzański, B., Czerwiński, Z., Borek, S., Kępka, M., Majsterkiewicz, T., 1971. Wpływ związków chemicznych stosowanych do odśnieżania na zasolenie gleb zieleńców Warszawy. Roczniki Gleboznawcze - Soil Science Annual 22(1), 59-74. (in Polish with English and Russian abstract)

Dobrzański, B., Czerwiński, Z., Pracz, J., Mazurek, A., 1977. Procesy glebowe i właściwości gleb aglomeracji miejskiej na przykładzie Ogrodu Saskiego w Warszawie. Człowiek i Środowisko 1, 33-44.

Drab, M., 1988. Charakterystyka właściwości fizyko-chemicznych gleb powstałych na terenach poeksploatacyjnych kruszywa budowlanego w Dobroszowie Wielkim k. Nowogrodu w woj. zielonogórskim. Zesz. Nauk. WSInż. Zielona Góra, 84, 105-121.

Drab, M., 1998. Badania nad przywracaniem produktywności gruntów po eksploatacji kruszywa budowlanego. II. Plony roślin uprawnych. Zeszyty Naukowe PZ 116, 147-159.

Drab, M., 2002. The effects of biological reclamation of the former "Dobroszów Wielki” building aggregate deposit in the Lubuskie Province. Editorial Office of Scientific and Technical Publishers, $112 \mathrm{pp}$.

Drab, M., 2004. The influence of land reclamation activity on forming of selected properties of grounds that had originated as a result of natural aggregate mining in Dobroszów region of Lubuskie province. Roczniki Gleboznawcze - Soil Science Annual 55(2), 85-94. (in Polish with English abstract)

Dradrach, A., Bogacz, A., 2013. Niektóre właściwości gleb wybranych trawników ulicznych i osiedlowych Wrocławia. Zeszyty Naukowe Uniwersytetu Przyrodniczego we Wrocławiu, Rolnictwo 596, 19-33.

Dradrach, A., Szopka, K., Karczewska, A. 2019. Ecotoxicity of pore water in soils developed on historical arsenic mine dumps: The effects of forest litter. Ecotoxicology and Environmental Safety 181, 202-213. https://doi.org/10.1016/j.ecoenv.2019.05.079
Dradrach, A., Karczewska, A., Szopka, K., 2020a. Arsenic accumulation by red fescue (Festuca rubra) growing in mine affected soils - Findings from the field and greenhouse studies. Chemosphere 248, 126045. https://doi.org/10.1016/j.chemosphere.2020.126045

Dradrach, A., Karczewska, A., Szopka, K., Lewińska, K., 2020b. Accumulation of arsenic by plants growing in the sites strongly contaminated by historical mining in the Sudetes region of Poland. International Journal of Environmental Research and Public Health 17(9), 3342. https://doi.org/10.3390/ijerph17093342

Dradrach, A., Szopka, K., Karczewska, A. 2020c. Ecotoxicity of pore water in meadow soils affected by historical spills of arsenic-rich tailings. Minerals 10(9), 751. https://doi.org/10.3390/min10090751

Dziewoński, K., 1955. A new branch of geographic research - urban physiography. Przegląd Geograficzny 27(3-4), 489-500. (in Polish with English and Russian summaries)

Eckes, T., Gołda, T., Gruszczyński, S., Żuławski, C., 1986. Zasady projektowania rekultywacji zwałowisk. Archiwum Ochrony Środowiska 1-4, 143-155. (in Polish)

Fabiańska, M.J., Ciesielczuk, J., Misz-Kennan, M., Kruszewski, Ł., Kowalski, Ł., 2016. Preservation of coal-waste geochemical markers in vegetation and soil on self-heating coal-waste dumps in Silesia, Poland. Chemie der Erde 76, 211-226. http://dx.doi.org/10.1016/ j.chemer.2016.04.001

Filipek, T., Badora, A., 1992. Jony rozpuszczalne w wodzie w glebach zanieczyszczonych środkami do zwalczania śliskości pośniegowej. Roczniki Gleboznawcze - Soil Science Annual 43(3/4), 37-43. (in Polish with English abstract)

Gałuszka, A., Migaszewski, Z.M., Dołęgowska, S., Michalik, A., DuczmalCzernikiewicz, A., 2015. Geochemical background of potentially toxic trace elements in soils of the historic copper mining area: a case study from Miedzianka Mt., Holy Cross Mountains, south-central Poland. Environmental Earth Sciences 74(6), 4589-4605. https://doi. org/10.1007/s12665-015-4395-6

Gałuszka, A., Migaszewski, Z., Duczmal-Czernikiewicz, A., Dołęgowska, S., 2016. Geochemical background of potentially toxic trace elements in reclaimed soils of the abandoned pyrite-uranium mine (south-central Poland). International Journal of Environmental Science and Technology 13(11), 2649-2662. https://doi.org/10.1007/s13762-0161095-z

Gałuszka, A., Migaszewski, Z.M., Dołęgowska, S., Michalik, A., 2018. Geochemical anomalies of trace elements in unremediated soils of Mt. Karczówka, a historic lead mining area in the city of Kielce, Poland. Science of The Total Environment 639, 397-405. https://doi. org/10.1016/j.scitotenv.2018.05.174

Gawron, M., Chodak, T., Szerszeń, L., 2007. Selected properties of afterflotation wastes from "Konrad" no. 1 reservoir in Iwiny with regard to their utility for biological reclamation. Zeszyty Naukowe Uniwersytetu Zielonogórskiego 133, 95-102.

Gąsiorek, M., Kowalska, J., Mazurek, R., Pająk, M., 2017. Comprehensive assessment of heavy metal pollution in topsoil of historical urban park on an example of the Planty Park in Krakow (Poland). Chemosphere 179, 148-158. https://doi.org/10.1016/j.chemosphere.2017.0 3.106

Gersztyn, L., Karczewska, A., 2012. Specjacja miedzi w osadach poflotacyjnych górnictwa miedzi wzbogaconych w różne dodatki organiczne. Czasopismo Naukowo-Kulturalne, 33-39.

Gersztyn, L., Cuske, M., Karczewska, A., Galka, B., 2013. Wpływ zakwaszenia i alkalizacji na rozpuszczalność cynku w osadach poflotacyjnych. Episteme 3, 419-427.

Gilewska, M., 1991. Rekultywacja biologiczna gruntów pogórniczych na przykładzie KWB „Konin”. Roczniki AR w Poznaniu, Rozprawy Naukowe, nr 211.

Gilewska, M., 2004. Biological reclamation of power plant lignite ash dump sites. Roczniki Gleboznawcze - Soil Science Annual 55(2), 103-110. (in Polish with English abstract) 
Gilewska, M., 2006. Utilization of wastes in reclamation of post mining soils and ash dump sites. Roczniki Gleboznawcze - Soil Science Annual 57(1/2), 75-81. (in Polish with English abstract)

Gilewska, M., Otremba, K., 2007. Grunty pogórnicze Kopalni Węgla Brunatnego „Konin” jako materiał macierzysty gleb. Warsztaty 2007 z cyklu: Zagrożenia naturalne w górnictwie, Materiały Warsztatów, 39-48.

Gilewska, M., Otremba, K., 2013. Revitalisation of post-mining regions in the area of the town of Konin. Zeszyty Naukowe UZ 150(30), 59-67. (in Polish with English abstract)

Gilewska, M., Otremba, K., Kozłowski, M. 2020. Physical and chemical properties of ash from thermal power station combusting lignite. A case study from central Poland. Journal of Elementology 25(1), 279-295. 10.5601/jelem.2019.24.4.1886

Gmochowska, W., Pietranik, A., Tyszka, R., Ettler, V., Mihaljevič, M., Długosz, M., Walenczak, K., 2019. Sources of pollution and distribution of $\mathrm{Pb}, \mathrm{Cd}$ and $\mathrm{Hg}$ in Wrocław soils: Insight from chemical and $\mathrm{Pb}$ isotope composition. Chemie der Erde 79, 434-445. https://doi. org/10.1016/j.chemer.2019.07.002

Gołda, T., 2003. Uwarunkowania prac rekultywacyjnych w kopalni siarki „Jeziórko” w wyniku wywołanych przekształceń w środowisku glebowo-wodnym. Próba syntetycznej oceny. Inżynieria Środowiska 8(1), 29-43. (in Polish)

Gołda, T., Haładus, A., Kulma, R., 2005. Geosozologiczne skutki likwidacji kopalń siarki w rejonie Tarnobrzega. Inżynieria Środowiska 10(1), 59-73. (in Polish)

Gołębiowska, J., Bender, J., 1983. Czynniki warunkujące powstawanie poziomu próchniczego w procesie rekultywacji zwałowisk. Archiwum Ochrony Środowiska 1-2, 65-75.

Gołuchowska, B., Wróbel, R., 2018. Magnetic susceptibility spatial distribution as an indicator of soil pollution in the area of Opole city. Ecological Chemistry and Engineering A 25(2), 167-185.

Greinert, A., 1998a. Ecology and urban studies. I. Transformation of soils in Zielona Góra. Ecology in Border Region. IBEN, Gorzów Wielkopolski. 76-81. (in Polish)

Greinert, A., 1998b. Ecology and urban studies. II. Soil contaminants sources in Zielona Góra. Ecology in Border Region. IBEN, Gorzów Wielkopolski. 85-90. (in Polish)

Greinert, A., 1998c. Ecology and urban studies. III. Pollution of soils in Zielona Góra - Comparison with other Polish cities. Ecology in Border Region. IBEN, Gorzów Wielkopolski. 97-101. (in Polish)

Greinert, A., 1999a. Ecology and urban studies. IV. Danger of heavy metal accumulation in urban green areas. Ecology in Border Region. IBEN, Gorzów Wielkopolski. 83-87. (in Polish)

Greinert, A., 1999b. Ecology and urban studies. V. Is pollution extraction from soils an ecological method? Ecology in Border Region. IBEN, Gorzów Wielkopolski. 63-67. (in Polish)

Greinert, A., 2000a. Soils of the Zielona Góra urban area. Transformation of the soils as a result of urbanization processes [In:] First International Conference on Soils of Urban, Industrial, Traffic and Mining Areas : Proceedings. Essen, Vol. 1 : The Unknown Urban Soil, Detection, Resources and Faces, 33-38.

Greinert, A. 2000b. The content of skeleton in topsoil layers of urban soils as an indicator of their degree of anthropogenic transformation on the example of the city of Zielona Góra. Zeszyty Naukowe PZ, Inżynieria Środowiska 124(10), 107-114.

Greinert, A., 2000c. Ecology and urban studies. VI. Lawns as a substantial element of urban greenery. Ecology in Border Region. IBEN, Gorzów Wielkopolski. 296-300. (in Polish)

Greinert, A., 2000d. Ecology and urban studies. VII. Urban green areas in the light of Polish legal regulations. Ecology in Border Region. IBEN, Gorzów Wielkopolski. 163-166. (in Polish)

Greinert, A., 2002. Böden Urbanisierter Räume am Beispel von Zielona Góra und Gorzów Wlkp. Grund und Bodenverunreinigung sowie deren Ausmass und Möglichkeiten der Beseitigung - IV Deutsch-Polnisches Symposium. Zielona Góra, 85-102. (in German)
Greinert, A., 2003. Studies on soils of the Zielona Góra urban area. University of Zielona Góra Publ. House, Zielona Góra. (in Polish)

Greinert, A., 2015. The heterogeneity of urban soils in the light of their properties. Journal of Soils and Sediments 15(8), 1725-1737. https:// doi.org/10.1007/s11368-014-1054-6

Greinert, A., 2017. Functions of soils in the urban environment, [In:] Maxine, J.L., Kye-Hoon, J.K., Morel, J.-L., Burghardt, W., Charzyński, P, Shaw, R.K., (Eds.), Soils within cities. Global approaches to their sustainable management - composition, properties, and functions of soils of the urban environment. Schweizerbart Science Publisher, 43-52.

Greinert, A., Kostecki, J., 2019. Anthropogenic Materials as Bedrock of Urban Technosols, [In:] Vasenev et al., V., (eds.) Urbanization: Challenge and Opportunity for Soil Functions and Ecosystem Services. Proceedings of the $9^{\text {th }}$ SUITMA Congress. Berlin, Springer International Publishing AG, 11-20.

Greinert, A., Fruzińska, R., Kostecki, J., 2013a. Urban soils in Zielona Góra, [In:] Charzyński, P., Hulisz, P., Bednarek, R., (eds.) Technogenic soils of Poland. Torun, Polish Society of Soil Science, 31-54.

Greinert, A., Drab, M., Kostecki, J., Fruzińska, R., 2013b. Post-mining soils in Łęknica region, [In:] Charzyński, P., Hulisz, P. Bednarek, R. (eds.), Technogenic soils of Poland. Toruń, Polish Society of Soil Science, 233-253.

Greinert, A., Bazan-Krzywoszańska, A., Drab, M., Fiszer, J., Gontaszewska, A., Jachimko, B., Jędrczak, A., Kraiński, A., Krzaklewski, W., Maciantowicz, M., Naworyta, W., Pietrzykowski, M., Skiba, M., Uzarowicz, Ł., 2015. Wydobycie węgla brunatnego i rekultywacja terenów pokopalnianych w regionie lubuskim. University of Zielona Góra Publ. House, 350 pp.

Greinert, A., Drab, M., Śliwińska, A., 2018. Storage capacity of organic carbon in the reclaimed post-mining technosols. Environment Protection Engineering 44(1), 117-127, https://doi.org/10.5277/epe180109

Greinert, H., 1988. Charakterystyka właściwości gleb powstałych w wyniku rekultywacji terenów po eksploatacji węgla brunatnego w rejonie Łęknicy. Zeszyty Naukowe WSInż. w Zielonej Górze, Zielona Góra 84, 93-104.

Greinert, H., 1995. Wpływ podwyższonego poziomu nawożenia NPK na efektywność leśnej rekultywacji zwałowisk po kopalni węgla brunatnego. ZPPNR, z. 418, cz. 2, 637-642.

Greinert, H., 1996. Rekultywacja leśna utworów pokopalnianych w rejonie Łęknicy. Zeszyty Naukowe PZ, 114. Inżynieria Środowiska 6, 91-111.

Greinert, H., 1997. Problemy związane z rekultywacją terenów pogórniczych na Środkowym Nadodrzu. II Światowy Kongres Ochrony Środowiska na Terenach Górniczych, Katowice, T. 1, 535-542.

Greinert, H., Drab, M., 2000. Physical properties of the soil formed as a result of recultivation of sand-pits in the Bóbr river valley. Acta Agrophysica 35, 77-84.

Greinert, H., Drab, M., Greinert, A., 2009. Studies on the effectiveness of forest restoration of the phytotoxic acid Miocene sands dumps of the former lignite mine in Łęknica. Oficyna Wyd. Uniwersytetu Zielonogórskiego, Zielona Góra, 173 pp. (in Polish)

Gwiżdż, M., Kabała, C., 2011. Skuteczność rekultywacji biologicznej składowisk odpadów z górnictwa węgla kamiennego. Przegląd Górniczy 67(6), 103-106.

Gwiżdż, M., Pruchniewicz, D., Kabała, C., Szopka, K., 2010. Kierunki docelowego zagospodarowania składowisk odpadów wydobywczych na przykładzie wybranych obiektów Wałbrzyskiego i Rybnickiego Okręgu Węglowego. Przegląd Górniczy 66, 78-85.

Hołtra, A., Zamorska-Wojdyła, D., 2018. The input of trace elements from the motor transport into urban soils of Wrocław, Poland. Science of the Total Environment 631-632, 1163-1174. https://doi.org/10.1016/ j.scitotenv.2018.03.096

Hulisz, P., Michalski, A., Dąbrowski, M., Kusza, G., Łęczyński, L., 2015. Human-induced changes in the soil cover at the mouth of the Vis- 
tula River Cross-Cut. Soil Science Annual 66(2), 67-74. https://doi. org/10.1515/ssa-2015-0021

Hulisz, P., Charzyński, P., Greinert, A., 2018a. Urban soil resources of medium-sized cities in Poland: a comparative case study of Torun and Zielona Góra. Journal of Soils and Sediments 18, 358-372. https://doi. org/10.1007/s11368-016-1596-x

Hulisz, P., Pindral, S., Kobierski, M., Charzyński, P., 2018b. Technogenic layers in organic soils as a result of the impact of the soda industry. Eurasian Soil Science 51(10), 1133-1141. https://doi.org/10.1134/ S1064229318100046

IUSS Working Group WRB, 2015. World Reference Base for Soil Resources 2014, update 2015. International soil classification system for naming soils and creating legends for soil maps. World Soil Resources Reports No. 106. FAO, Rome.

Jankowski, M., Sewerniak, P., 2013. Soils of bare lands in the Torun military area [In:] Charzyński, P., Hulisz, P., Bednarek, R., (eds.) Technogenic soils of Poland. Toruń, Polish Society of Soil Science, 323-343.

Jankowski, M., Bednarek, R., Jaworska, M., 2013. Soils constructed on the 19th century fortifications in Torun. [In:] Charzyński, P., Hulisz, P., Bednarek, R., (eds.) Technogenic soils of Poland. Toruń, Polish Society of Soil Science, 345-357.

Jerzykowska, I., Majzlan, J., Michalik, M., Gottlicher, J., Steininger, R., Błachowski, A., Ruebenbauer, K., 2014. Mineralogy and speciation of $\mathrm{Zn}$ and As in Fe-oxide-clay aggregates in the mining waste at the MVT $\mathrm{Zn}-\mathrm{Pb}$ deposits near Olkusz, Poland. Chemie der Erde - Geochemistry, 74, 393-406. https://doi.org/10.1016/j.chemer.2014.03.003

Józefowska, A., Pietrzykowski, M., Woś, B., Cajthaml, T., Frouz, J., 2017. The effects of tree species and substrate on carbon sequestration and chemical and biological properties in reforested post-mining soils. Geoderma 292, 9-16. https://doi.org/10.1016/j.geoderma.2017.01.008

Józefowska, A., Sokołowska, J., Woźnica, K., Woś, B., Pietrzykowski, M., 2019. Tree species and soil substrate affect buffer capacity of anthroposols in afforested postmine sites in Poland. Journal of Soil and Water Conservation 74, 372-379. https://doi.org/10.2489/jswc.74.4.372

Józefowska, A., Woś, B., Pietrzykowski, M., 2016. Tree species and soil substrate effects on soil biota during early soil forming stages at afforested mine sites. Applied Soil Ecology 102, 70-79. https://doi.org/10.1016/ j.apsoil.2016.02.012

Józefowska, A., Woś, B., Pietrzykowski, M., Schlaghamerský, J., 2020. Colonisation by enchytraeids as a suitable indicator of successful biological reclamation of post-mining technosols using alders. Applied Soil Ecology 145. https://doi.org/10.1016/j.apsoil.2019.06.003

Kabała, C., 1995. Próba określenia tendencji zmian właściwości gleb Tomaszowa Mazowieckiego. ZPPNR, 418, 323-328. (in Polish with English abstract)

Kabała, C., Buczak, M., Gałka, B., Chodak, T., 2010. Anthropogenic transformations and classification of the soils in rural park in WroclawPawlowice. Roczniki Gleboznawcze - Soil Science Annual 61(4), 69-77. (in Polish with English abstract)

Kabała, C., Charzyński, P., Chodorowski, J., Drewnik, M., Glina, B., Greinert, A., Hulisz, P., Jankowski, M., Jonczak, J., Łabaz, B., Łachacz, A., Marzec, M., Mendyk, Ł., Musiał, P., Musielok, Ł., Smreczak, B., Sowiński, P., Świtoniak, M., Uzarowicz, Ł., Waroszewski, J., 2019. Polish Soil Classification, $6^{\text {th }}$ edition - principles, classification. Soil Science Annual 70(2), 71-97. https://doi.org/10.2478/ssa-2019-0009

Kabała, C., Chodak, T., 2002. Gleby. W: Środowisko Wrocławia. Dolnośląska Fundacja Ekorozwoju, Wrocław, 66-73.

Kabala, C., Chodak, T., Szerszen, L., Karczewska, A., Szopka, K., Fratczak, U., 2009. Factors influencing the concentration of heavy metals in soils of allotment gardens in the city of Wroclaw, Poland. Fresenius Environmental Bulletin 18(7), 1118-1124.

Kabala, C., Galka, B., Jezierski, P., 2020. Assessment and monitoring of soil and plant contamination with trace elements around Europe's largest copper ore tailings impoundment. Science of The Total Environment, 738, 139918. https://doi.org/10.1016/j.scitotenv.2020.139918
Kabala, C., Galka, B., Labaz, B., Anjos, L., de Souza Cavassani, R., 2018. Towards more simple and coherent chemical criteria in a classification of anthropogenic soils: A comparison of phosphorus tests for diagnostic horizons and properties. Geoderma 320,1-11. https://doi. org/10.1016/j.geoderma.2018.01.024

Kabala, C., Karczewska, A., Szopka, K., Wilk, J., 2011. Copper, zinc, and lead fractions in soils long-term irrigated with municipal wastewater. Communications in Soil Science and Plant Analysis 42(8), 905-919. https://doi.org/10.1080/00103624.2011.558960

Kabala, C., Szlachta, T., 2000. Całkowita zawartość oraz formy rozpuszczalne pierwiastków śladowych w odpadach serpentynitowych kopalni Nasławice. Zeszyty Problemowe Postępów Nauk Rolniczych 471(2), 959-966.

Kabała, C., Wilk, J., 2004. Sequential extraction of iron and zinc in soils irrigated with municipal wastewater. Roczniki PZH 55, 133-141.

Kabała, C., Greinert, A., Charzyński, P., Uzarowicz, Ł., 2020. Technogenic soils - a group soil of the year 2020 in Poland. Concept, properties and classification of technogenic soils in Poland. Soil Science Annual 71(4), 267-280. https://doi.org/10.37501/soilsa/131609

Kabata-Pendias, A., 1977. Accumulation of heavy metals by plants grown on gangue slurries of a copper mine. Roczniki Gleboznawcze - Soil Science Annual 28(2), 141-154. (in Polish with English abstract)

Karczewska, A., 1999. Metale ciężkie w glebach i roślinach na hałdach pogórniczych dawnych ośrodków górnictwa i hutnictwa miedzi w Parku Krajobrazowym Chełmy. Ochrona Środowiska i Zasobów Naturalnych 18, 177-186.

Karczewska, A., 2014. Historically contaminated sites and their remediation in the light of Act on environmental protection amended in 2014 - selected cases from South-Western Poland. Zeszyty Naukowe Uniwersytetu Przyrodniczego we Wrocawiu, Rolnictwo 607.

Karczewska, A., Bogda, A., 2006. Heavy metals in soils of former mining areas in the Sudety Mountains-their forms and solubility. Polish Journal of Environmental Studies 15(2a), 104-110.

Karczewska, A., Milko, K., 2010. Effects of chelating agents on copper, lead and zinc solubility in polluted soils and tailings produced by copper industry. Ecological Chemistry and Engineering - A 17(4-5), 395-403.

Karczewska, A., Kabała, C., 2017. Environmental risk assessment as a new basis for evaluation of soil contamination in Polish law. Soil Science Annual 68(2), 67-80. https://doi.org/10.1515/ssa-2017-0008

Karczewska, A., Bogda, A., Kurnikowska, B., 2001. Nickel, chromium, lead and cadmium in soils and common plant species in the area of nickel mining and smelting (Szklary, SW Poland). Proceedings of $6^{\text {th }}$ ICOBTE, Guelph, GP327, 570.

Karczewska, A., Bogda, A., Gałka, B., Krajewski, J., 2005. Assessment of environmental hazards in the vicinity of polymetallic ore deposits Żeleźniak (Wojcieszów-Kaczawskie Mts, SW Poland). Wyd. Akademii Rolniczej we Wrocławiu, 262.

Karczewska, A., Bogda, A., Krysiak, A., 2007. Arsenic in soils in the areas of former mining and mineral processing in Lower Silesia, southwestern Poland. Trace Metals and other Contaminants in the Environment 9, 411-440. https://doi.org/10.1016/S1875-1121(06)09016-X

Karczewska, A., Gersztyn, L., Galka, B., 2011. Wpływ różnie ustabilizowanych osadów ściekowych na rozpuszczalność $\mathrm{Cu}, \mathrm{Pb}$ i As w osadach poflotacyjnych przemysłu miedziowego i arsenowego. Zeszyty Problemowe Postępów Nauk Rolniczych 564, 103-113.

Karczewska, A., Gersztyn, L., Galka, B., Juszczyszyn, M., Kantek, K., 2013. Effects of sewage sludge application on arsenic species in polluted soils. Fresenius Environmental Bulletin 22(4), 962-967.

Karczewska, A., Kaszubkiewicz, J., Kabała, C., Jezierski, P., Spiak, Z., Szopka, K., 2017. Tailings impoundments of Polish copper mining industry - environmental effects, risk assessment and reclamation. [In:] Bech, J., Bini, C., Pashkevich, M. (eds.), Assessment, restoration and reclamation of mining influenced soils. Academic Press, pp. 149-202.

Karczewska, A., Lewińska, K., Siepak, M., Gałka, B., Dradrach, A., Szopka, K., 2018. Transformation of beech forest litter as a factor that triggers 
arsenic solubility in soils developed on historical mine dumps. Journal of Soils and Sediments 18(8), 2749-2758. https://doi.org/10.1007/ s11368-018-2031-2

Karczewska, A., Lewińska, K., Siepak, M., Gałka, B., 2019. Lanthanides in soils of historical mining sites in Poland. Polish Journal of Environmental Studies 28(3), 1517-1522. https://doi.org/10.15244/ pjoes/85673

Kasowska, D., Gediga, K., Spiak, Z., 2018. Heavy metal and nutrient uptake in plants colonizing post-flotation copper tailings. Environmental Science and Pollution Research 25(1), 824-835. https://doi.org/10.1007/ s11356-017-0451-y

Kierczak, J., Neel, C., Aleksander-Kwaterczak, U., Helios-Rybicka, E., Bril, H., Puziewicz, J., 2008. Solid speciation and mobility of potentially toxic elements from natural and contaminated soils: A combined approach. Chemosphere 73, 776-784. https://doi.org/10.1016/j.chemosp here.2008.06.015

Kierczak, J., Potysz, A., Pietranik, A., Tyszka, R., Modelska, M., Néel, C., Ettler, V., Mihaljevič, M., 2013. Environmental impact of the historical Cu smelting in the Rudawy Janowickie Mountains (south-western Poland). Journal of Geochemical Exploration 124, 183-194. https://doi. org/10.1016/j.gexplo.2012.09.008

Kochanowska, K., Kusza, G., 2010. Wpływ zasolenia na właściwości fizyko-chemiczne gleb Opola w latach 1994 i 2009. Inżynieria Ekologiczna 23, 14-21. (in Polish with English abstract)

Komornicki, T., 1986. Soils of the Planty park in Kraków. Roczniki Gleboznawcze - Soil Science Annual 37(4), 187-200. (in Polish with English abstract)

Konecka-Betley, K., Janowska, E., Łuniewska-Broda, J., Szpotański, M., 1984. Wstępna klasyfikacja gleb aglomeracji warszawskiej. Roczniki Gleboznawcze - Soil Science Annual 35(2), 151-163. (in Polish with English and Russian abstract)

Kordas, L., Tasz, W., 2012. Plonowanie oraz zawartość makroelementów w wybranych roślinach energetycznych uprawianych na zmodyfikowanych dodatkiem materiałów mineralnych i organicznych odpadach z flotacji rud miedzi. Fragmenta Agronomica 29(3), 103-113.

Kostecki, J., Greinert, A., Wasylewicz, R., Adam, R., Garbera, B., Knap, P., Ostapkowicz, M., Stanisławiak, B., 2015. Spatial distribution of heavy metals in the topsoil on roundabouts in Zielona Góra, Poland. Enviromental Protection and Natural Resources 26(2), 1-8.

Kostecki, J., Greinert, A., Drab, M., Mik, Ł., 2020. Soil sealing on example of the Jędrzychów Residential Area in Zielona Góra, Poland. Civil and Environmental Engineering Reports 30(1), 53-63. https://doi. org/10.2478/ceer-2020-0005

Kowalik, S. Wójcik, J., 2005. Symptoms of the development of soil-making process under young reclamation forestations on the floor of the old working of the Sand Mine "Szczakowa”. Inżynieria Środowiska 10(2), 185-194 (in Polish).

Kowalik, S., 2004. Chemical properties of anthrosoils of agricultural and forestry management of the waste heap of Sulphur Mine "Machów". Roczniki Gleboznawcze - Soil Science Annual 55(2), 239-249. (in Polish with English abstract)

Kowalska, J., Mazurek, R., Gąsiorek, M., Setlak, M., Zaleski, T., Waroszewski, J., 2016. Soil pollution indices conditioned by medieval metallurgical activity - A case study from Krakow (Poland). Environmental Pollution 218, 1023-1036. https://doi.org/10.1016/j.envpol.2016.08.053

Kozanecka, T., Czarnowska, K., Kwasowski, W., 2000. Accumulation of heavy metals In the soils near petrol stations in Warsaw. Roczniki Gleboznawcze - Soil Science Annual 51(1/2), 73-78. (in Polish with English abstract)

Krawczyńska, M., Kołwzan, B., Gediga, K., Dziubek, A. M., Grabas, K., Karpenko, E., 2015. Evaluation of the possibility of phytostabilization of post-flotation tailing ponds. Environment Protection Engineering 41(1), 157-167.

Krupski, M., Kabala, C., Sady, A., Gliński, R., Wojcieszak, J., 2017. Double-and triple-depth digging and Anthrosol formation in a medieval and modern-era city (Wrocław, SW Poland). Geoarchaeological research on past horticultural practices. Catena 153, 9-20. https://doi. org/10.1016/j.catena.2017.01.028

Kruszewski, Ł., 2013. Supergene sulphate minerals from the burning coal mining dumps in the Upper Silesian Coal Basin, South Poland. International Journal of Coal Geology 105, 91-109. http://dx.doi. org/10.1016/j.coal.2012.12.007

Krysiak, A., Karczewska, A., 2007. Arsenic extractability in soils in the areas of former arsenic mining and smelting, SW Poland. Science of the Total Environment 379(2-3), 190-200. https://doi.org/10.1016/ j.scitotenv.2006.09.031

Krzaklewski, W., Barszcz, J., Małek, S., Kozioł, K., Pietrzykowski, M., 2004. Contamination of forest soils in the vicinity of the sedimentation pond after zinc and lead ore flotation (in the region of Olkusz, Southern Poland). Water, Air, and Soil Pollution 159, 151-164. https://doi. org/10.1023/B:WATE.0000049173.18935.71

Krzaklewski, W., Mikłaszewski, A., 1996. Rekultywacja zwałów nadkładu w górnictwie węgla brunatnego w Polsce. Pr. Nauk. Inst. Górnictwa Polit. Wrocł. 79, 215-218.

Krzaklewski, W., Pietrzykowski, M. 2002. Selected physico-chemical properties of zinc and lead ore tailings and their biological stabilisation. Water Air and Soil Pollution 141(1-4), 125-142. https://doi.org/10.1023/ A:1021302725532

Krzaklewski, W., Pietrzykowski, M., Woś, B., 2012. Survival and growth of alders (Alnus glutinosa (L.) Gaertn. and Alnus incana (L.) Moench) on fly ash technosols at different substrate improvement. Ecological Engineering 49, 35-40. https://doi.org/10.1016/ j.ecoleng.2012.08.026

Krzaklewski, W., Wójcik, J., 2008. Zalesienia jako metoda rekultywacji terenów bezglebowych na wybranym przykładzie górnictwa odkrywkowego KWB “Adamów” Mat. VIII Symp. Ochrony Ekosystemów Leśnych. Zagrożenia ekosystemów leśnych przez człowieka. Wyd. SGGW, Warszawa.

Kuc, P., Kordas, L., Lejcuś, K., 2019. Phytostabilisation of tailing ponds with use of water absorbing geocomposites and organic and mineral additives. Environment Protection Engineering 45(1), 71-81.

Kukier, U., 1985. Stan zanieczyszczenia metalami ciężkimi wierzchniej warstwy gleb Lublina. Ann. UMCS, Sec. B, 219-228.

Kukier, U., 1991. Metale ciężkie w atmosferze i glebach Lublina. Archiwum Ochrony Środowiska 2, 117-138.

Kusza, G., Hulisz, P., Łęczyński, L., Michalski, A., Dąbrowski, M., Kłostowska, Ż., 2018. Application of magnetic susceptibility measurements for identification of technogenic horizons in soil profiles on the example of the Vistula River Cross-Cut area. [In:] Jeleńska, M., Łęczyński, L., Ossowski, T., (eds.), GeoPlanet: Earth and Planetary Sciences. Magnetometry in Environmental Sciences, 65-78.

Kwasowski, W., Markiewicz, M., 2007. Content of heavy metals in soils of the kitchen garden nearby the accumulator factory in Piastów. Zeszyty Problemowe Postępów Nauk Rolniczych 520, 531-537.

Kwasowski, W., Kozanecka, T., Górska, E., Gozdowski, D., Kowalczyk, P., 2016. Application of heavy metals in street dust in the monitoring of changes in environment. Fresenius Environmental Bulletin 25(1), 103-112.

Lemanowicz, J., Brzezińska, M., Siwik-Ziomek, A., Koper, J., 2020. Activity of selected enzymes and phosphorus content in soils of former sulphur mines. Science of The Total Environment 708, 134545. https:// doi.org/10.1016/j.scitotenv.2019.134545

Lewińska, K., Karczewska, A., Siepak, M., Gałka, B., Stysz, M., Kaźmierowski, C., 2017. Recovery and leachability of antimony from mine and shooting range soils. Journal of Elementology 22(1), 70-90. https://doi. org/10.5601/jelem.2016.21.1.1115

Lewińska, K., Karczewska, A., Siepak, M., Szopka, K., Gałka, B., Iqbal, M., 2019. Effects of waterlogging on the solubility of antimony and arsenic in variously treated shooting range soils. Applied Geochemistry 105, 7-16. https://doi.org/10.1016/j.apgeochem.2019.04.005 
Licznar, S.E., Licznar, M., 2005. Wrocław agglomeration impact on humus horizons of the Szczytnicki Park’s soil. Roczniki Gleboznawcze - Soil Science Annual 56(1/2), 113-118. (in Polish with English abstract)

Licznar, S.E, Licznar, M., Licznar, P., 2007. Monitoring środowiska: Badania pokrywy glebowej Parku Szczytnickiego we Wrocławiu. Inst. Badań Systemowych PAN, Badania Systemowe 53, 104 pp.

Likus-Cieślik, J., Pietrzykowski, M., 2017. Vegetation development and nutrients supply of trees in habitats with high sulfur concentration in reclaimed former sulfur mines Jeziórko (Southern Poland). Environmental Science and Pollution Research 24, 20556-20566. https://doi. org/10.1007/s11356-017-9638-5

Likus-Cieślik, J., Pietrzykowski, M., Chodak, M., 2018. Chemistry of sulfur-contaminated soil substrate from a former Frasch extraction method sulfur mine leachate with various forms of litter in a controlled experiment. Water, Air, and Soil Pollution 229, 71. https://doi. org/10.1007/s11270-018-3716-2

Likus-Cieślik, J., Pietrzykowski, M., Szostak, M., Szulczewski, M., 2017. Spatial distribution and concentration of sulfur in relation to vegetation cover and soil properties on a reclaimed sulfur mine site (Southern Poland). Environmental Monitoring and Assessment 189, 87. https://doi.org/10.1007/s10661-017-5803-z

Likus-Cieślik, J., Smoliński, A., Pietrzykowski, M., Bąk, A., 2019. Sulphur contamination impact on seasonal and surface water chemistry on a reforested area of a former sulphur mine. Land Degradation and Development 30, 212-225. https://doi.org/10.1002/ldr.3216

Łuczak, K., Kusza, G., 2019. Magnetic susceptibility in the soils along communication routes in the town of Opole. Journal of Ecological Engineering 20(2), 234-238. https://doi.org/10.12911/22998993/99782

Łuczak, K., Pisarek, I., Kusza, G., 2020. The use of mineral materials for salinity control in roadside soils. Archives of Environmental Protection 46(2), 83-90. https://doi.org/10.24425/aep.2020.133478

Łukasik, A., Szuszkiewicz, M., Magiera, T., 2015. Impact of artifacts on topsoil magnetic susceptibility enhancement in urban parks of the Upper Silesian conurbation datasets. Journal of Soils and Sediments 15, 1836-1846. https://doi.org/10.1007/s11368-014-0966-5

Maciak, F., 1978. Effect of the seven-year recultivation on an ash dump of the Konin power plant on yielding of cocksfoot and some changes of soil. Roczniki Gleboznawcze - Soil Science Annual 29(3), 203-216. (in Polish with English abstract)

Maciak, F., Liwski, S., Biernacka, E., 1974. Some physico-chemical and biochemical properties of the ash dumps after brown and hard coal. Roczniki Gleboznawcze - Soil Science Annual 25(3), 191-205. (in Polish with English abstract)

Maciak, F., Liwski, S., Biernacka, E., 1976b. Agricultural recultivation on furnace waste (ash) dumps from brown and hard coal. Part II. Chemical composition of plants cultivated on brown and hard coal ash dumps. Roczniki Gleboznawcze - Soil Science Annual 27(4), 171-187. (in Polish with English abstract)

Maciak, F., Liwski, S., Biernacka, E., 1976c. Agricultural recultivation of furnace waste (ash) dumps from brown and hard coal. Part III. Course of soil-forming processes in ash dumps under influence of grass and leguminous vegetation. Roczniki Gleboznawcze - Soil Science Annual 27(4), 189-209. (in Polish with English abstract)

Maciak, F., Liwski, S., Jeżewski, Z., 1979. Recultivation of a brown coal dump at the Konin power plant by means of planting of trees and shrubs. Roczniki Gleboznawcze - Soil Science Annual 30(3), 179-198. (in Polish with English abstract)

Maciak, F., Liwski, S., Prończuk, J., 1976a. Agricultural recultivation of furnace waste (ash) dumps from brown and hard coal. Part I. Vegetation growth on ash dumps depending on agronomic measures and fertilization. Roczniki Gleboznawcze - Soil Science Annual 27(4), 149-169. (in Polish with English abstract)

Maciejewska, A., Bogda, A., 2003. Changes of chosen properties of soils of coal mining stores in Walbrzych region under vegetation influence. Zeszyty Problemowe Postępów Nauk Rolniczych 493, 923-929.
Magiera, T., Strzyszcz, Z., 2000. Using of field magnetometry in estimation of urban soil degradation. Proceedings of First International Conference on Soils of Urban, Industrial, Traffic and Mining Areas, vol. 1. Universitat-GH Essen, Essen, Germany, 105-110.

Magiera, T., Strzyszcz, Z., Kapička, A., Petrovský, E., 2006. Discrimination of lithogenic and anthropogenic influences on topsoil magnetic susceptibility in Central Europe. Geoderma 130, 299-311. https://doi. org/10.1016/j.geoderma.2005.02.002

Magiera, T., Parzentny, H., Łukasik, A., 2016a. The influence of the wind direction and plants on the variability of topsoil magnetic susceptibility in industrial and urban areas of southern Poland. Environmental Earth Sciences 75, 213. https://doi.org/10.1007/s12665-015-4846-0

Magiera, T., Mendakiewicz, M., Szuszkiewicz, M., Jabłońska, M. Chróst, L., 2016b. Technogenic magnetic particles in soils as evidence of historical mining and smelting activity: a case of the Brynica River Valley, Poland. Science of the Total Environment 566-567, 536-551. https:// doi.org/10.1016/j.scitotenv.2016.05.126

Majgier, L., Rahmonov, O., 2012. Selected chemical properties of necrosols from the abandoned cemeteries Słabowo and Szymonka (Great Mazurian Lakes District). Bulletin of Geography, Physical Geography Series 5(1), 43-55. https://doi.org/10.2478/v10250-012-0003-8

Majgier, L., Rahmonov, O., Bednarek, R., 2014. Features of abandoned cemetery soils on sandy substrates in Northern Poland. Eurasian Soil Science 47, 621-629. https://doi.org/10.1134/S1064229314060064

Malczyk, P., Kędzia, W., Nowak, M., 1996. Heavy metals in soils of the Bydgoszcz city. Roczniki Gleboznawcze - Soil Science Annual 47(3-4), 195-202. (in Polish with English abstract)

Marczyk, M., Kaszubkiewicz, J., Patrzałek, A., Bartoszczuk, P., 2013. Dynamika zawartości niektórych metali ciężkich i właściwości fizyczno-chemicznych rekultywowanych odpadów poflotacyjnych. Zeszyty Naukowe Uniwersytetu Przyrodniczego we Wrocławiu, Rolnictwo 592.

Markiewicz, M., Hulisz, P., Charzyński, P., Piernik, A., 2018. Characteristics of soil organic matter of edifisols - An example of techno humus system. Applied Soil Ecology 123, 509-512. https://doi.org/10.1016/ j.apsoil.2017.04.022

Mazurek, R., Kowalska, J., Gąsiorek, M., Setlak, M., 2016. Micromorphological and physico-chemical analyses of cultural layers in the urban soil of a medieval city - A case study from Krakow, Poland. Catena 141, 73-84. https://doi.org/10.1016/j.catena.2016.02.026

Mendyk, Ł., Charzyński, P., 2016. Soil sealing degree as factor influencing urban soil contamination with polycyclic aromatic hydrocarbons (PAHs). Soil Science Annual 67(1), 17-23. https://doi.org/10.1515/ssa2016-0003

Migaszewski, Z., Gałuszka, A., Dołęgowska, S., 2015. The use of FPXRF in the determinations of selected trace elements in historic mining soils in the Holy Cross Mts., south-central Poland. Geological Quarterly 59(2), 248-256. https://gq.pgi.gov.pl/article/view/13878.

Musielok, Ł., Drewnik, M., Stolarczyk, M., Gus, M., Bartkowiak, S., Kożyczkowski, K., Lasota, J., Motak, A., Szczechowska, K., Wątły, M., 2018. Rates of anthropogenic transformation of soils in the Botanical Garden of Jagiellonian University in Kraków (Poland). Catena 170, 272-282. https://doi.org/10.1016/j.catena.2018.06.023

Oktaba, L., Odrobińska, D., Uzarowicz, Ł., 2018. The impact of different land uses in urban area on humus quality. Journal of Soils and Sediments 18(8), 2823-2832. https://doi.org/10.1007/s11368-018-1982-7

Oktaba, L., Paziewski, K., Kwasowski, W., Kondras, M., 2014. The effect of urbanization on soil properties and soil organic carbon accumulation in topsoil of Pruszków - a medium-sized city in the Warsaw Metropolitan Area, Poland. Soil Science Annual 65(1), 10-17. https://doi. org/10.2478/ssa-2014-0002

Oleszczuk, P., Baran, S., 2005. The content of polycyclic aromatic hydrocarbons in soils under different anthropogenic influence. Roczniki Gleboznawcze - Soil Science Annual 56(3/4), 67-77. (in Polish with English abstract) 
Orzechowski, M., Smólczyński, S., Wyrzykowski, A., 2008. Soil properties of reclaimed sites of sand and gravel post-mine "Sarnowo" in mazowieckie voivodeship. Roczniki Gleboznawcze - Soil Science Annual 59(2), 170-176. (in Polish with English abstract)

Pająk, M., Błońska, E., Frąc, M., Oszust, K., 2016. Functional diversity and microbial activity of forest soils that are heavily contaminated by lead and zinc. Water Air and Soil Pollution 227, 348. https://doi. org/10.1007/s11270-016-3051-4

Pająk, M., Błońska, E., Szostak, M., Gąsiorek, M., Pietrzykowski, M., Urban, O., Derbis, P., 2018. Restoration of vegetation in relation to soil properties of spoil heap heavily contaminated with heavy metals. Water Air and Soil Pollution 229, 392. https://doi.org/10.1007/s11270018-4040-6

Pająk, M., Krzaklewski, W., 2006. Selected chemical properties of initial soils on the outside spoil bank of the "Bełchatów" Mine. Roczniki Gleboznawcze - Soil Science Annual 57(1/2), 158-163. (in Polish with English abstract)

Pardela, Ł., Kowalczyk, T., Bogacz, A., Kasowska, D., 2020. Sustainable green roof ecosystems: 100 years of functioning on fortifications - A case study. Sustainability 12(11), 4721. https://doi.org/10.3390/su12114721

Pasieczna, A., 2003. Atlas zanieczyszczeń gleb miejskich w Polsce. PIG, Warszawa. (in Polish)

Piernik, A., Hulisz, P., Rokicka, A., 2015. Micropattern of halophytic vegetation on technogenic soils affected by the soda industry. Soil Science and Plant Nutrition 61, Suppl. 1, 98-112. https://doi.org/10.1080/0038 0768.2015.1028874

Pietranik, A., Kierczak, J., Tyszka, R., Schulz, B., 2018. Understanding heterogeneity of a slag-derived weathered material: The role of automated SEM-EDS analyses. Minerals 8, 1-19. https://doi.org/10.3390/ $\min 8110513$

Pietrzykowski, M., 2014. Soil quality index as a tool for Scots pine (Pinus sylvestris) monoculture conversion planning on afforested, reclaimed mine land. Journal of Forestry Research 25(1), 63-74. https:// doi.org/10.1007/s11676-013-0418-x

Pietrzykowski, M., Krzaklewski, W., 2007. Soil organic matter, C and N accumulation during natural succession and reclamation in an opencast sand quarry (southern Poland). Archives of Agronomy and Soil Science 53, 473-483.

Pietrzykowski, M., Daniels, W.L., 2014. Estimation of carbon sequestration by pine (Pinus sylvestris L.) ecosystems developed on reforested postmining sites in Poland on differing mine soil substrates. Ecological Engineering 73, 209-218. https://doi.org/10.1016/j.ecoleng.2014.09.058

Pietrzykowski, M., Likus-Cieślik, J., 2018. Comprehensive study of reclaimed soil, plant, and water chemistry relationships in highly S-contaminated post sulfur mine site Jeziórko (Southern Poland). Sustainability (Switzerland) 10, 2442. https://doi.org/10.3390/su10072442

Pietrzykowski, M., Krzaklewski, W., Gaik, G., 2010a. Assessment of forest growth with plantings dominated by scots pine (Pinus sylvestris L.) on experimental plots on a fly ash disposal site at the Bełchatów Power Plant. University of Zielona Góra, Scientifical Reports, Environmental Engineering 137(17), 64-74. (in Polish with English abstract)

Pietrzykowski, M., Pająk, M., Krzaklewski, W., 2010b. The assessment of possibility of using soil quality estimation numerical methods based on the Forest Soil Trophism Index (ITGL) and Soil Site Index (SIG) for description of habitat conditions on spoil heap KWB "Bełchatów" reclaimed to forest. Gospodarka Surowcami Mineralnymi 26(3), 155-165. (in Polish with English abstract)

Pietrzykowski, M., Krzaklewski, W., Piechnik, Ł., 2011. Soil characteristics on afforested areas after calamine mining. Roczniki Gleboznawcze Soil Science Annual 62(2), 325-334. (in Polish with English abstract)

Pietrzykowski, M., Krzaklewski, W., Woś, B., 2013. Concentration of trace elements ( $\mathrm{Mn}, \mathrm{Zn}, \mathrm{Cu}, \mathrm{Cd}, \mathrm{Pb}, \mathrm{Cr}$ ) in alder (Alnus sp.) leaves used as phytomelioration species on fly ash disposal. University of Zielona Góra, Scientifical Reports, Environmental Engineering 151(31), 26-34. (in Polish with English abstract)
Pietrzykowski, M., Gruba, P., Sproull, G., 2017. The effectiveness of Yellow lupine (Lupinus luteus L.) green manure cropping in sand mine cast reclamation. Ecological Engineering 102, 72-79.

Pietrzykowski, M., Woś, B., Pająk, M., Wanic, T., Krzaklewski, W., Chodak, M., 2018a. Reclamation of a lignite combustion waste disposal site with alders (Alnus sp.): assessment of tree growth and nutrient status within 10 years of the experiment. Environmental Science and Pollution Research 25, 17091-17099. https://doi.org/10.1007/s11356-0181892-7

Pietrzykowski, M., Woś, B., Pająk, M., Wanic, T., Krzaklewski, W., Chodak, M., 2018b. The impact of alders (Alnus spp.) on the physico-chemical properties of technosols on a lignite combustion waste disposal site. Ecological Engineering 120, 180-186. https://doi.org/10.1016/ j.ecoleng.2018.06.004

Pindral, S, Kot, R, Hulisz, P, Charzyński, P., 2020. Landscape metrics as a tool for analysis of urban pedodiversity. Land Degradation and Development, 1-14. https://doi.org/10.1002/ldr.3601

Piotrowska-Długosz, A., Charzyński, P., 2015. The impact of the soil sealing degree on microbial biomass, enzymatic activity, and physicochemical properties in the Ekranic Technosols of Torun (Poland). Journal of Soils and Sediments 15, 47-59. https://doi.org/10.1007/s11368-0140963-8

Plak, A., 2018. Functions of the city and the content and distribution of heavy metals, metalloids and rare earth elements in urban soils. UMCS in Lublin Publ. House, 294 pp.

Polish Soil Classification (Systematyka Gleb Polski), 2011. Roczniki Gleboznawcze - Soil Science Annual 62(3), 1-193. (in Polish with English summary)

Polish Soil Classification (Systematyka Gleb Polski), 2019. Soil Science Society of Poland, Commission on Soil Genesis, Classification and Cartography. Wydawnictwo Uniwersytetu Przyrodniczego we Wrocławiu, Polskie Towarzystwo Gleboznawcze, Wrocław - Warszawa: 235 pp. (in Polish with English summary)

Potysz, A., Grybos, M., Kierczak, J., Guibaud, G., Fondaneche, P., Lens, P.N.L., van Hullebusch, E.D., 2017. Metal mobilization from metallurgical wastes by soil organic acids. Chemosphere 178, 197-211. https:// doi.org/10.1016/j.chemosphere.2017.03.015

Potysz, A., Kierczak, J., Grybos, M., Pędziwiatr, A., van Hullebusch, E.D., 2018. Weathering of historical copper slags in dynamic experimental system with rhizosphere-like organic acids. Journal of Environmental Management 222, 325-337. https://doi.org/10.1016/ j.jenvman.2018.05.071

Potysz, A., Pędziwiatr, A., Hedwig, S., Lenz, M., 2019. Rapid metal mobilisation through litter, water and bioweathering as the legacy of historical copper smelting. Journal of Geochemical Exploration 206, 106364. https://doi.org/10.1016/j.gexplo.2019.106364

Rachwał, M., Magiera, T., Wawer, M., 2015. Coke industry and steel metallurgy as the source of soil contamination by technogenic magnetic particles, heavy metals and polycyclic aromatic hydrocarbons. Chemosphere 138, 863-873. https://doi.org/10.1016/j.chemosphere.20 14.11.077

Rachwał, M., Wawer, M., Magiera, T., Steinnes, E., 2017. Integration of soil magnetometry and geochemistry for assessment of human health risk from metallurgical slag dumps. Environmental Science and Pollution Research 24, 26410-26423. https://doi.org/10.1007/s11356-0170218-5

Racinowski, R., 1976. Wprowadzenie do fizjografii urbanistycznej. Wyd. Pol. Szczec., Szczecin, 236 pp.

Rosik-Dulewska, C., Dulewski, J., 1988. Estimation of fodder quality of plants cultivated on hard coal dumps of the "Halemba" power plant. Roczniki Gleboznawcze - Soil Science Annual 39, 265-285. (in Polish with English and Russian abstract)

Roszyk, E., Roszykowa, S., 1975. Ołów w glebach i roślinach w pobliżu dróg na terenie Wrocławia. Roczniki Gleboznawcze - Soil Science Annual 26(1), 177-185. (in Polish with English and Russian abstract) 
Roszyk, E., Strojek, Z., 1983. Influence of the industrial works producing zinc white and minium on the environment contamination. Roczniki Gleboznawcze - Soil Science Annual 34(1-2), 161-166. (in Polish with English and Russian abstract)

Różański, S.Ł., Kwasowski, W., Peńas Castejón, J.M., Hardy, A., 2018. Heavy metal content and mobility in urban soils of public playgrounds and sport facility areas, Poland. Chemosphere 212, 456-466. https://doi. org/10.1016/j.chemosphere.2018.08.109

Siwik-Ziomek, A., Brzezińska, M., Lemanowicz, J., Koper, J., Szarlip, P., 2018. Biological parameters in technogenic soils of a former sulphur mine. International Agrophysics 32, 237-245. https://doi.org/10.1515/ intag-2017-0011

Skawina, T., 1958a. The processes of soil deterioration in mining and industrial regions. Roczniki Gleboznawcze - Soil Science Annual 7 (suppl.), 131-148. (in Polish with English abstract)

Skawina, T., 1958b. The development of soil formation processes on the waste heaps of the coal industry. Roczniki Gleboznawcze - Soil Science Annual 7(suppl.), 149-162. (in Polish with English abstract)

Skawina, T., 1963. Rekultywacja terenów poeksploatacyjnych górnictwa odkrywkowego węgla brunatnego. Węgiel Brunatny 3, 151-242. (in Polish)

Skawina, T., 1969. Results of researches on the model of re-vegetation of exploited mining areas. Zeszyty Naukowe AGH, nr 12, Geodezja, z. 12, Kraków, 115-136. (in Polish with English abstract)

Skawina, T., Trafas M., 1971. Zakres wykorzystania i sposób interpretacji wyników badań geologicznych dla potrzeb rekultywacji. Ochrona Terenów Górniczych 16, 3-10. (in Polish)

Skawina, T., Trafas, M., Gołda, T., 1974. Rekultywacja terenów pogórniczych kopalni pirytu „Siarkopol” w Rudkach k. Kielc. Zeszyty Naukowe AGH, nr 466, Sozologia i Sozotechnika, z. 4, Kraków, 9-21. (in Polish with English abstract)

Skiba, S., Drewnik, M., Szymański, W., Żyła, M., 2013. Gleby. [In:] Degórska, B., Baścik, M. (eds.), Środowisko przyrodnicze Krakowa: zasobyochrona-kształtowanie. Instytut Geografii i Gospodarki Przestrzennej Uniwersytetu Jagiellońskiego, Kraków - Warszawa, 69-79.

Smólczyński, S., Orzechowski, M., 2010. Water capacity and content of exchangeable cations in the soils of reclaimed sand and gravel postmine areas. Roczniki Gleboznawcze - Soil Science Annual 61(3), 111-120. (in Polish with English abstract)

Smólczyński, S., Orzechowski, M., Kalisz, B., Krupiński, K., 2020. Selected properties of reclaimed mine soils in the area of a former gravel mine in north-eastern Poland. Soil Science Annual 71(1), 66-75. https://doi. org/10.37501/soilsa/121493

Spiak, Z., Gediga, K., Kaszubkiewicz, J., Grabas, K., Kołwzan, B., Mizera, W., Szpadt, R., 2012. Ocena możliwości wykorzystania odpadów do rewitalizacji zdegradowanych terenów poprzemysłowych. Wydawnictwo Uniwersytetu Przyrodniczego we Wrocławiu, 1-158.

Spychalski, W., Mocek, A., Gilewska, M., Owczarzak, W., Otremba, K., 2016. Możliwości rekultywacji i wykorzystania rolniczego gruntów pogórniczych na przykładzie doświadczenia prowadzonego na zwałowisku odkrywki węgla brunatnego Pątnów. Wyd. UP w Poznaniu, $136 \mathrm{pp}$.

Stępniewska, H., Uzarowicz, Ł., Błońska, E., Kwasowski, W., Słodczyk, Z., Gałka, D., Hebda, A., 2020. Fungal abundance and diversity as influenced by properties of Technosols developed from mine wastes containing iron sulphides: A case study from abandoned iron sulphide and uranium mine in Rudki, south-central Poland. Applied Soil Ecology 145C, 103349. https://doi.org/10.1016/j.apsoil.2019.08.011

Strączyńska, S., Strączyński, S., 2007. Characterisation of industrial soils under cultures of silver birch. Roczniki Gleboznawcze - Soil Science Annual 58(3/4), 126-131. (in Polish with English abstract)

Strączyńska, S., Strączyński, S., 2008. Estimation of habitat conditions under trees planted on reclaimed power plant ash dumps. Roczniki Gleboznawcze - Soil Science Annual 59(2), 223-229. (in Polish with English abstract)
Strączyńska, S., Strączyński, S., Cieścińska, B., Gwiżdż, M., 2009. Organic matter properties in the surface layer anthropogenic soils in Bełchatów region. Roczniki Gleboznawcze - Soil Science Annual 60(3), 139-144. (in Polish with English abstract)

Strączyńska, S., Strączyński, S., Gazdowicz, W., 2004. The influence of cover vegetation on morphological characteristics and some properties of embankment formation of furnace discards dump. Roczniki Gleboznawcze - Soil Science Annual 55(2), 397-404. (in Polish with English abstract)

Strzemski, M., 1955. Problems of urban soil science. Przegląd Geograficzny 27(3-4), 579-587. (in Polish with English and Russian summaries)

Strzyszcz, Z., 1978. Chemiczne przemiany utworów karbońskich w aspekcie biologicznej rekultywacji i zagospodarowania centralnych zwałowisk. Prace i Studia PAN 19. (in Polish, with English summary)

Strzyszcz, Z., 1980. Physical, physical-chemical and chemical properties of wastes after flotation of zinc and lead ores in aspect of their biological reclaiming. Archiwum Ochrony Środowiska 3-4, 19-50. (in Polish with English abstract)

Strzyszcz, Z., 1988. Natural basis of dump reclamation in underground hard coal mining. Zeszyty Naukowe AGH, nr 1222, Sozologia i Sozotechnika 26, 159-173. (in Polish with English abstract)

Strzyszcz, Z., 1989a. Anwesenheit des ferromagnetischen Eisen in oberschlesischen Waldböden und deren Ursachen. Mitteilungen der Bodenkundlichen Gesellschaft 59,1197-1202. (in German)

Strzyszcz Z., 1989b. Ferromagnetic properties of forest soils being under influence of industrial pollution. Air pollution and forest decline. [In] Proc. 14 ${ }^{\text {th }}$ Int. Meeting for Specialist in Air Pollution Effects on Forest Ecosystems, IUFRO, Interlaken, 201-269.

Strzyszcz, Z., Harabin, Z. 2004. Reclamation and biological management of coal mining wastes taking into special consideration central heaps. Instytut Podstaw Inżynierii Środowiska PAN, Zabrze. (in Polish with English abstract)

Strzyszcz, Z., Rachwał, M., 2010. Zastosowanie magnetometrii do monitoringu i oceny ekologicznej gleb na obszarach objętych wpływem emisji przemysłowych. Instytut Podstaw Inżynierii Środowiska PAN, Works \& Studies 78, ss. 89.

Strzyszcz, Z., Tölle, R., Katzur, J., 1988. Zur Anwendung eins hochfrequenten Messverfahrens für den Nachweiß von ferromagnetischen Eisen in der Umwelt. Archives of Environmental Protection 3-4, 137-143. (in German)

Strzyszcz, Z., Magiera, T., Bzowski, Z., 1994. Magnetic susceptibility as indicator of soils contamination in some regions of Poland. Roczniki Gleboznawcze - Soil Science Annual 44(supl.), 85-93.

Sutkowska, K., Teper, L., 2015. Impact of Solvay waste alkalinity on the leaching of heavy metals in a 100 year-old landfill. Proceedings of the World Congress on New Technologies (NewTech 2015), Barcelona, Spain, July 15-17, Paper No. 169.

Sutkowska, K., Teper, L., Stania, M. 2015. Tracing potential soil contamination in the historical Solvay soda ash plant area, Jaworzno, Southern Poland. Environmental Monitoring and Assessment 187, 704. https://doi.org/10.1007/s10661-015-4930-7

Swałdek, M., 1983. Przekształcenia pokrywy glebowej i zbiorowisk roślinnych w Staropolskim Okręgu Przemysłowym. Dokumentacja Geograficzna IGiPZ PAN, z. 4, pp. 96. (in Polish with English abstract)

Swęd, M.K., Niedzielski, P., 2018. Geochemistry and mineralogy of technogenic soils developed on old mine heaps of abandoned iron ore mines in the Ławęczna area (Holy Cross Mountains, south-central Poland). Soil Science Annual 69(1), 28-38. https://doi.org/10.2478/ssa2018-0004

Świątek, B., Woś, B., Chodak, M., Maiti, S.K., Józefowska, A., Pietrzykowski, M., 2019. Fine root biomass and the associated $\mathrm{C}$ and nutrient pool under the alder (Alnus spp.) plantings on reclaimed technosols. Geoderma 337, 1021-1027. https://doi.org/10.1016/ j.geoderma.2018.11.025 
Świtoniak, M., Hulisz, P., Kałucka, I., Różański, S., 2011. Role of Scots pine monocultures on the formation of organic carbon resources in soils on an external dumping ground of the Bełchatów open-cast lignite mine. Roczniki Gleboznawcze - Soil Science Annual 62(2), 395-405. (in Polish with English abstract)

Szafrański, C., Stachowski, P., 1997. Skład granulometryczny i właściwości fizykowodne rekultywowanych gruntów pogórniczych. Roczniki Akademii Rolniczej w Poznaniu - CCXCII, Seria Melior. Inż. Środ., 18, 91-101.

Szerszeń, L., Chodak, T., Giernalczyk, M., 1994. Arsen w odpadach kopalni rud arsenowych i glebach w rejonie Złotego Stoku. Zeszyty Naukowe. Polska Akademia Nauk. Komitet Naukowy przy Prezydium PAN Człowiek i Środowisko 8, 51-53.

Szopka, K., Bogda, A., Karczewska, A., Gałka, B., Wojtkowiak, M., Pruchniewicz, D., 2010. Properties of waste rock deposited on mine spoils of hard coal mines in Nowa Ruda with the perspective of their biological reclamation. Zeszyty Naukowe UZ, Inżynieria Środowiska 138 (18), 5-11. (in Polish with English abstract)

Szuszkiewicz, M.M., Łukasik, A., Magiera, T., Szuszkiewicz, M., 2018. Technogenic Magnetic Particles of Topsoil from Different Sources of Emission - A case Study from Upper Silesian Conurbation. MATEC Web of Conferences 247, 00051. https://doi.org/10.1051/matecconf/201824700051

Trafas, M., 1988. Problemy i efekty rekultywacji osadników odpadów poflotacyjnych rud Zn i Pb na przykładzie osadnika ZG Trzebionka. Zeszyty Naukowe AGH, nr 1222, Sozologia i Sozotechnika, 26, 185-199.

Trafas, M., 1996. Changes in the properties of post-flotation wastes due to vegetation introduced during process of reclamation. Applied Geochemistry 11(1-2), 181-185. https://doi.org/10.1016/08832927(95)00062-3

Trafas, M., Eckes, T., 2007. Soil-making aspects in the evaluation of artificial formations; focus on the wastes formed after the flotation of zinc and lead ores. Geomatics and Environmental Engineering 1(2), 97-110. (in Polish)

Uzarowicz Ł., 2011. Technogenic soils developed on mine spoils containing iron sulfides in select abandoned industrial sites: Environmental hazards and reclamation possibilities. Polish Journal of Environmental Studies 20(3), 771-782.

Uzarowicz, Ł., 2013. Microscopic and microchemical study of iron sulphide weathering in a chronosequence of technogenic and natural soils. Geoderma 197-198C, 137-150. https://doi.org/10.1016/ j.geoderma.2013.01.006

Uzarowicz, Ł., Maciejewska, A., 2012. Ocena właściwości technogenicznych utworów glebowych Technosols zawierających siarczki żelaza (Assessment of properties of technogenic soils Technosols containing iron sulfides). Roczniki Gleboznawcze - Soil Science Annual 63(3), 37-42. https://doi.org/12.2478/v10239-012-0031-2

Uzarowicz, Ł., Skiba, S., 2011. Technogenic soils developed on mine spoils containing iron sulphides: Mineral transformations as an indicator of pedogenesis. Geoderma 163(1-2), 95-108. https://doi.org/10.1016/ j.geoderma.2011.04.008

Uzarowicz, Ł., Skiba, S., 2013. Technogenic soils developed from mine wastes containing iron sulphides in southern Poland. [In:] Technogenic soils of Poland (Ed. P. Charzyński, P. Hulisz, R. Bednarek), Polish Society of Soil Science, Toruń, 275-299.

Uzarowicz, Ł., Zagórski, Z., 2015. Mineralogy and chemical composition of technogen ic soils (Technosols) developed from fly ash and bottom ash from selected thermal power stations in Poland. Soil Science Annual 66, 82-91. https://doi.org/10.1515/ssa-2015-0023

Uzarowicz, Ł., Skiba, S., Skiba, M., Michalik, M., 2008. Mineral transformations in soils on spoil heaps of an abandoned pyrite mine in Wieściszowice (Rudawy Janowickie Mts., Lower Silesia). Polish Journal of Soil Science 41(2), 183-193.

Uzarowicz, Ł., Skiba, S., Skiba, M., Šegvić, B., 2011. Clay-mineral formation in soils developed in the weathering zone of pyrite-bearing schists:
A case study from the abandoned pyrite mine in Wieściszowice, Lower Silesia, Poland. Clays and Clay Minerals 59(6), 581-594. https://doi. org/10.1346/CCMN.2011.0590604

Uzarowicz, Ł., Šegvić, B., Michalik, M., Bylina, P., 2012. The effect of hydrochemical conditions and $\mathrm{pH}$ of the environment on phyllosilicate transformations in the weathering zone of pyrite-bearing schists in Wieściszowice (SW Poland). Clay Minerals 47(4), 401-417. https://doi. org/10.1180/claymin.2012.047.4.01

Uzarowicz, Ł., Zagórski, Z., Mendak, E., Bartmiński, P., Szara, E., Kondras, M., Oktaba, L., Turek, A., Rogoziński, R., 2017. Technogenic soils (Technosols) developed from fly ash and bottom ash from thermal power stations combusting bituminous coal and lignite. Part I. Properties, classification, and indicators of early pedogenesis. Catena 157, 75-89. https://doi.org/10.1016/j.catena.2017.05.010

Uzarowicz, Ł., Kwasowski, W., Śpiewak, O., Świtoniak, M., 2018a. Indicators of pedogenesis of Technosols developed in an ash settling pond at the Bełchatów thermal power station (central Poland). Soil Science Annual 69, 49-59. https://doi.org/10.2478/ssa-2018-0006

Uzarowicz, Ł., Skiba, M., Leue, M., Zagórski, Z., Gąsiński, A., Trzciński, J., 2018b. Technogenic soils (Technosols) developed from fly ash and bottom ash from thermal power stations combusting bituminous coal and lignite. Part II. Mineral transformations and soil evolution. Catena 162, 255-269. https://doi.org/10.1016/j.catena.2017.11.005

Uzarowicz, Ł., Wolińska, A., Błońska, E., Szafranek-Nakonieczna, A., Kuźniar, A., Słodczyk, Z., Kwasowski, W., 2020. Technogenic soils (Technosols) developed from mine spoils containing Fe sulphides: microbiological activity as an indicator of soil development following land reclamation. Applied Soil Ecology 156C, 103699. https://doi. org/10.1016/j.apsoil.2020.103699

Warchulski, R., Mendecki, M., Gawęda, A., Sołtysiak, M., Gadowski, M., 2019. Rainwater-induced migration of potentially toxic elements from a $\mathrm{Zn}-\mathrm{Pb}$ slag dump in Ruda Śląska in light of mineralogical, geochemical and geophysical investigations. Applied Geochemistry 109, 104396. https://doi.org/10.1016/j.apgeochem.2019.104396

Wawer, M., Magiera, T., Ojha, G., Appel, E., Bućko, M., Kusza, G., 2015a. Characteristics of current roadside pollution using test-monitoring plots. Science of the Total Environment 505, 795-804. https://doi. org/10.1016/j.scitotenv.2014.10.025

Wawer, M., Magiera, T., Ojha, G., Appel, E., Kusza, G., Hu, S., Basavaiah, N., 2015b. Traffic-related pollutants in roadside soils of different countries in Europe and Asia. Water Air and Soil Pollution 226, 216. https://doi.org/10.1007/s11270-015-2483-6

Wawer, M., Rachwał, M., Kowalska, J., 2017. Impact of noise barriers on the dispersal of solid pollutants from car emissions and their deposition in soil. Soil Science Annual 68(1), 19-26. https://doi.org/10.1515/ ssa-2017-0003

Weber, J., Strączyńska, S., Kocowicz, A., Gilewska, M., Bogacz, A., Gwiżdż, M., Dębicka, M., 2015. Properties of soil materials derived from fly ash 11 years after revegetation of post-mining excavation. Catena 133, 250-254. https://doi.org/10.1016/j.catena.2015.05.016

Winiarek, P., Kruk, A., 2017. Pesticide residues in soils along railway lines. Soil Science Annual 68(4), 189-196. https://doi.org/10.1515/ssa2017-0024

Wojcieszczuk, T., 1981. Ocena zasolenia gleb miejskich solami chlorkowymi, ich oddziaływanie na drzewa oraz możliwości zapobiegania skutkom nadmiernej akumulacji soli. Wyd. ZUP AR Szczecin, Nauka - Praktyce, 1-27. (in Polish with English abstract)

Wojcieszczuk, T., 1982. Ilościowe zmiany Na, Ca, K i Cl w glebach o różnym stopniu zasolenia w obrębie miasta Szczecina. ZN AR Szczecin, Seria Rolnictwo, 28, 94, 281-293. (in Polish with English abstract)

Wolińska, A., Włodarczyk, K., Kuźniar, A., Marzec-Grządziel, A., Grządziel, J., Gałązka, A., Uzarowicz, Ł., 2020. Soil microbial community profiling and bacterial metabolic activity of Technosols as an effect of soil properties following land reclamation: a case study from the abandoned iron sulphide and uranium mine in Rudki (south- 
central Poland). Agronomy 10, 1795. https://doi.org/10.3390/agronomy10111795

Wójcik, J. Kowalik, S., 2006. The formation of selected properties of the initial soil on the waste heap from copper mining, under forest-directed reclamation. Inżynieria Środowiska 11(1), 87-99. (in Polish)

Wójcik, J., 2003. Kształtowanie się wybranych właściwości fizycznych inicjalnych gleb na zwałowisku zewnętrznym KWB „Adamów”. Inżynieria Środowiska 8(2), 217-227. (in Polish with English abstract)

Wójcik, J., Krzaklewski, W., 2007. Accumulation of organic matter in the initial soils on the external waste heap of the „Adamów” lignite mine. Roczniki Gleboznawcze - Soil Science Annual 58(3/4), 151-159. (in Polish with English abstract)

Wójcik, J., Krzaklewski, W., 2019. Afforestation as a method of reclamation of soilless land in brown coal mining in Poland. Inżynieria Ekologiczna 20(1), 24-37. (in Polish with English abstract) https://doi. org/10.12912/23920629/106204

Wójcik, R., Zawadzki, Ł., 2011. Anion leachability from the top layer of the Cracow soda waste dumps. Environmental Protection and Natural Resources, 49, 433-442. (in Polish with English abstract)

Woś, B., Józefowska, A., Pająk, M., Chodak, M., Frouz, J., Pietrzykowski, M., 2020. Carbon and macronutrient budgets in an alder plantation grown on a reclaimed combustion waste landfill. Forests 11, 430. https://doi.org/10.3390/f11040430

Woś, B., Pietrzykowski, M., Józefowska, A., 2018. Reclaimed mine soil substrates and tree stands vs. successional forest floor vegetation: A case study of developing ecosystems on afforested mine sites. EcologicalEngineering 120, 504-512. https://doi.org/10.1016/j.ecoleng.2018.07.010

Woś, B., Pietrzykowski, M., Krzaklewski, W., 2014. Properties of humus in soils formed on afforested dumping ground of the sulphur mine. Sylwan 158, 893-900.

Woś, B., Sroka, K., Józefowska, A., Pietrzykowski, M., 2019. Mercury concentration in Technosols and alder tissue from a plantation on a combustion waste disposal site. Water, Air, and Soil Pollution 230, 259. https://doi.org/10.1007/s11270-019-4280-0

Wybieralski, J., Maciejewska, M., 1999. Ocena skażenia środowiska metalami ciężkimi w pobliżu stacji benzynowych Szczecina i okolic. Ekologia i Technika 7(1), 20-23. (in Polish with English abstract)

Wysocki, W., 1988b. Rekultywacja składowisk odpadów elektrowni węglowych, Zeszyty Naukowe AGH, nr 1222, Sozologia i Sozotechnika, 26, 231-239. (in Polish with English abstract)

Znamirowska-Karaś, I., 2001. The soil forming processes depending on the waste material of mica-schist, loam dumps in the Sudety Mts. Zeszyty Naukowe Uniwersytetu Zielonogórskiego 133, 95-102. (in Polish with English abstract)

Znamirowska-Karaś, I., 2002. Procesy glebotwórcze i glebowe zachodzące na terenach zdegradowanych geotechnicznie. Cuprum 22, 3-93. (in Polish with English abstract)

Żołnierz, L., Weber, J., Gilewska, M., Strączyńska, S., Pruchniewicz, D., 2016. The spontaneous development of understory vegetation on reclaimed and afforested post-mine excavation filled with fly ash. Catena 136, 84-90. https://doi.org/10.1016/j.catena.2015.07.013

\section{Słowa kluczowe}

Gleby technogeniczne

Gleby miejskie

Gleby terenów górniczych

SUITMA

\section{Badania gleb technogenicznych w Polsce: historia, współczesność i perspektywy na przyszłość}

\section{Streszczenie}

Gleby występujące na obszarach silnie przekształconych przez człowieka były przez długi czas ignorowane $\mathrm{w}$ dyskursie naukowym. Również gospodarcze wykorzystanie tych gleb było ograniczone ze względu na ich nieproduktywność. Jedynie duże tereny pogórnicze zrekultywowane w kierunku leśnym lub rolnym były bardziej interesujące zarówno z punktu widzenia badań naukowych, jak i ich praktycznego wykorzystania. W przypadku terenów pogórniczych termin „teren bezglebowy” był używany przez długi czas, zwłaszcza w odniesieniu do terenów nie rekultywowanych. W artykule opisano historyczne badania gleb technogenicznych w Polsce (opublikowane do końca XX wieku). Gleby technogeniczne terenów miejskich i przemysłowych pojawiły się w polskich rozważaniach naukowych $\mathrm{w}$ drugiej połowie XX wieku. W tamtych czasach badano głównie właściwości gleby na składowiskach odpadów poprzemysłowych jako podstawę do rekultywacji technicznej i biologicznej na składowiskach. Polskimi naukowcami, których należy uznać za pionierów w kreowaniu koncepcji i badań gleb technogenicznych, są: (1) Michał Strzemski, który zaproponował schemat klasyfikacji gleb na terenach miejskich i przemysłowych, a także nakreślił propozycje kierunków badań tych gleb, oraz (2) Tadeusz Skawina, który z sukcesem skupił się na badaniach dynamiki i kierunków procesów glebotwórczych na hałdach odpadów kopalnianych w kontekście ich rekultywacji. W artykule przedstawiono również współczesne badania gleb technogenicznych (pierwsze dwadzieścia lat XXI w.). Od początku XXI wieku badania naukowe nabrały tempa. Współcześnie polscy naukowcy mają duże osiągnięcia w badaniach gleb technogenicznych, w tym w badaniu ich właściwości, genezy, ewolucji, klasyfikacji, właściwości biologicznych itp. Ponadto, w artykule nakreślono zarys przyszłych badań, które mogą być potencjalnie wykonywane w następnych latach. 